\title{
الحذف في شعر عنترة بن شداد /دراسة بلاغية
}

د. صالح كاظم صكبان / جامعة واسط/ كلية التربية / قسم اللغة العربية

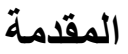

شعر عنترة بن شــاد العبسي ظـاهرة مهـمة من ظواهر الشعر الجـاهلي الذي مـازال

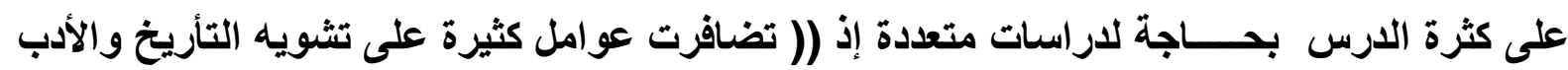

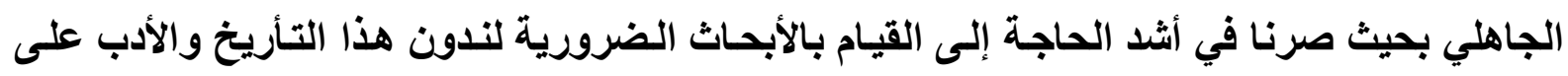

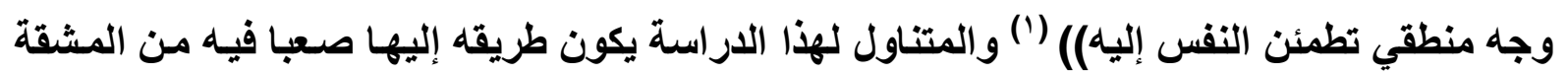

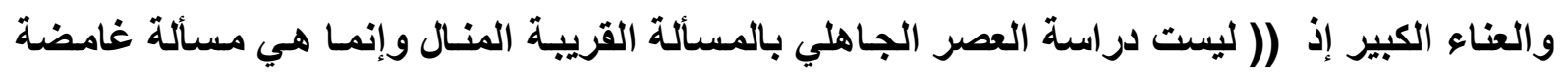

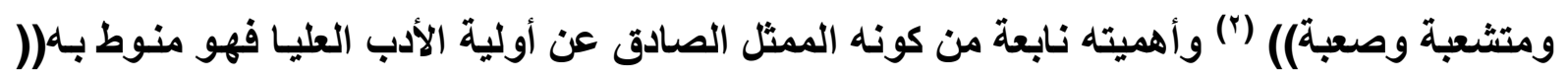

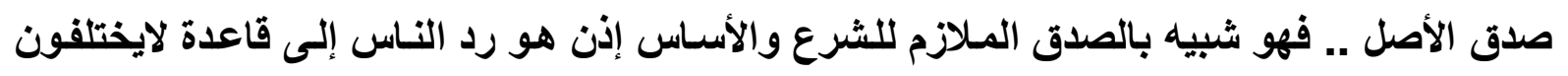

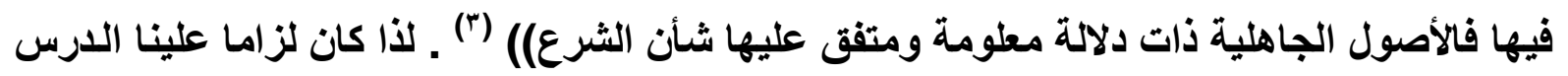
بهذا العصر بصورة مستفيضة ومن نواح عدة كي نرد على المقولات التي تحاول هدم هذا الصرح

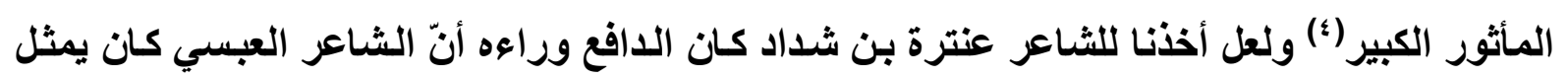

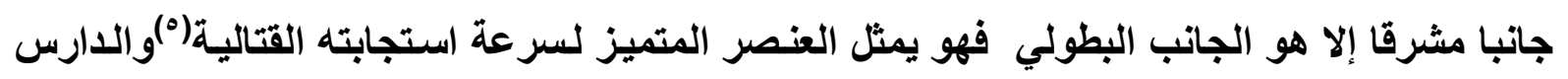

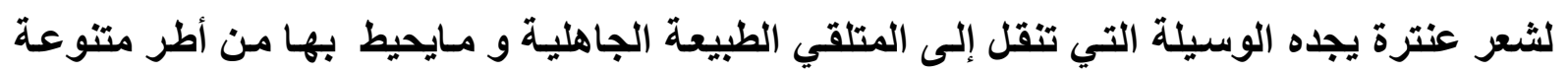

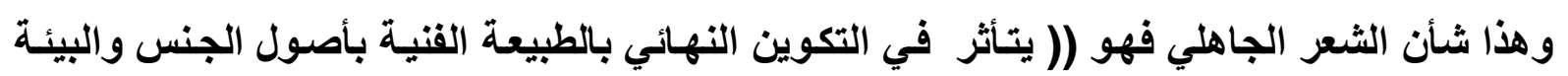

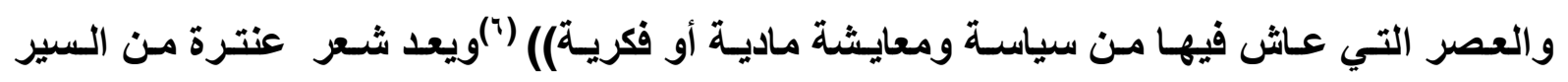

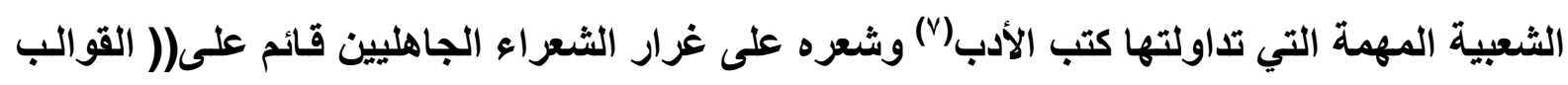

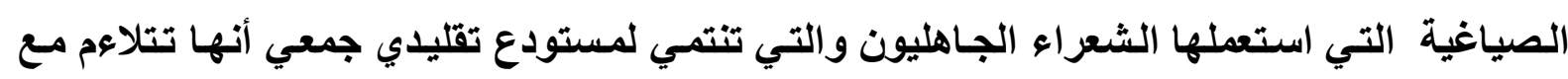

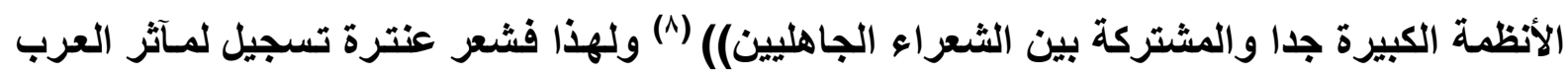

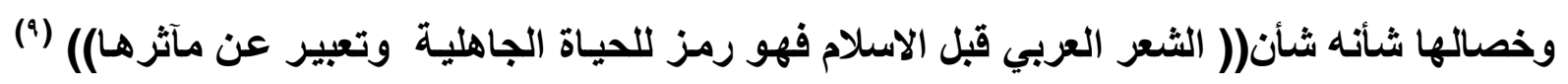

\footnotetext{
(1) المرأة في الشعر الجاهلي ،علي الهاشمي :17.

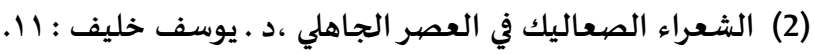

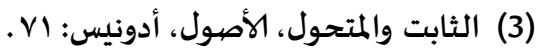

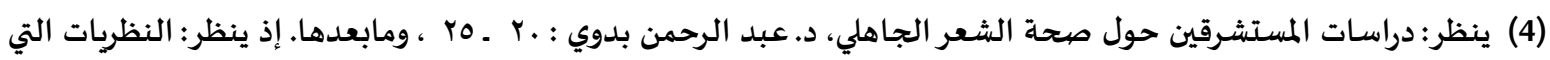
حاولت أن تهد الشعر الجاهلي.

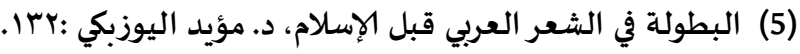

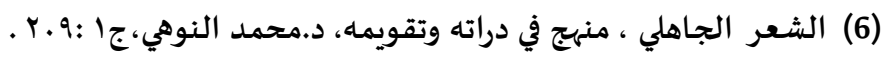

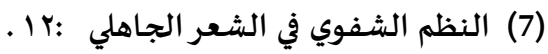

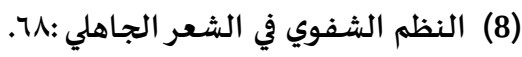

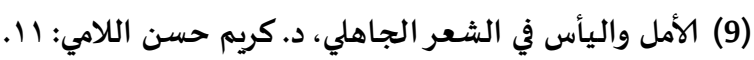


ونحن إذ ندخل في دراسة الحذف عند الثـاعر دراسة بلاغية فإنتا نحاول أن ندخل مباشرة إلى ماهية الطرح من أجل الكشف عن أسلوبية الشاعر في استعمال اسلوب الحذف وقدرتهه على جعل الكيان النحوي المتحول قادرا على إيصال الدلالة التي يروم الثاعر بثها ألى المتلقي.

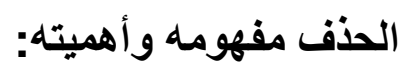

الحذف من موضوعات البلاغة العربية التي لها الأهمية الكبيرة في رصد الدلالة وهو من الموضوعات التي تتثارك بها البلاغة والنحو والفـارق بين النحوي والبلاغي يتمثل في أنَ البلاغي

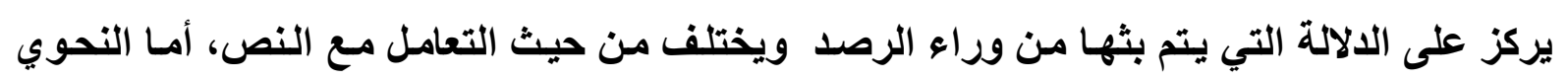

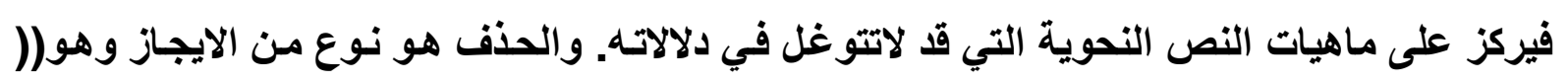

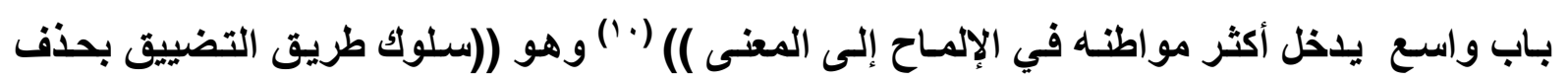

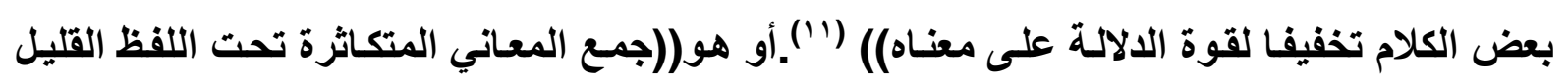

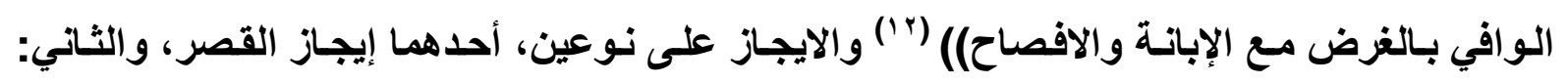

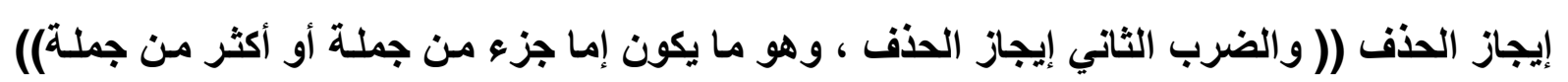
(ז') ولأهمية الحذف قال فيه صـاحب الصناعتين:(( الإيجاز قصور البلاغة على الحقيقة ومـا تجاوز

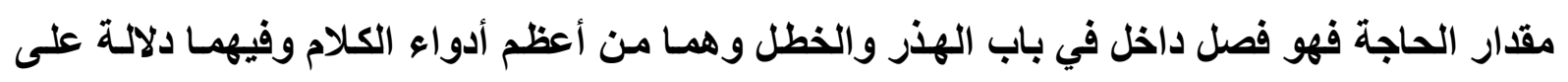
بلادة صاحب الصناعة)) (؛؛)". وقال عبد القاهر :((باب دقيق المسلك لطيف المأخذ عجيب الأمر شبيه

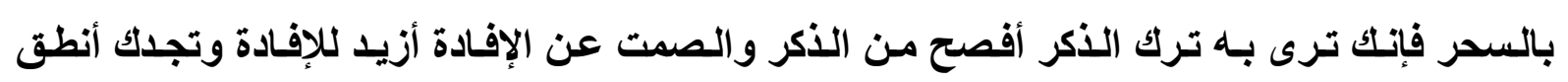

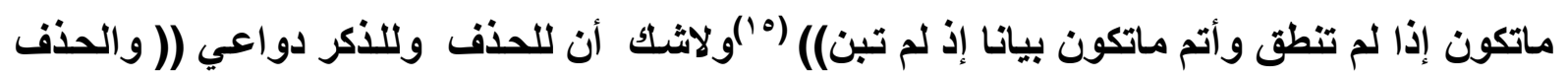

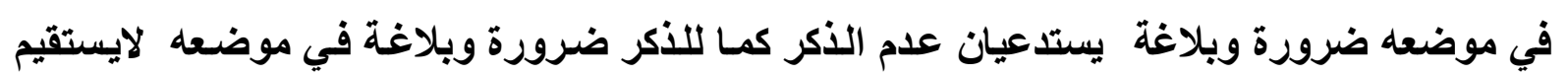

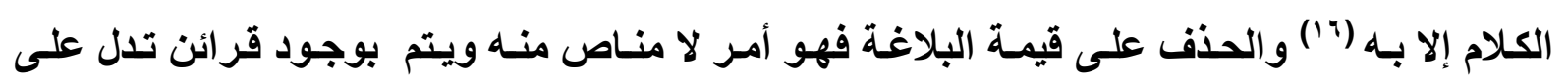

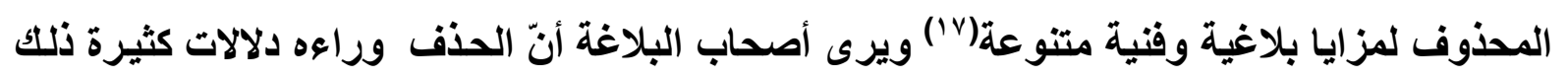

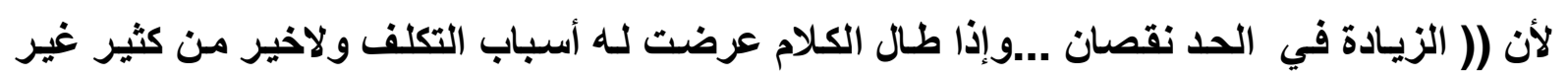

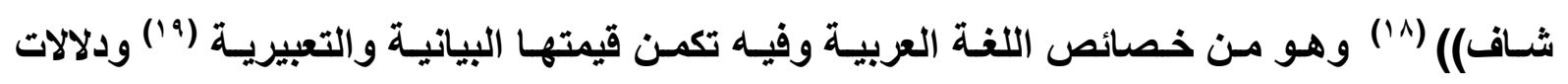

(10) الجملة العربية والمعنى،د. فاضل صالح السامرائي.

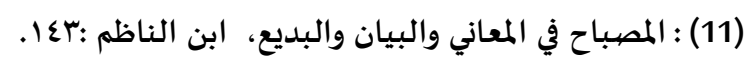

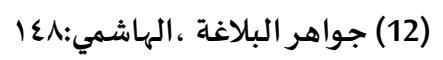

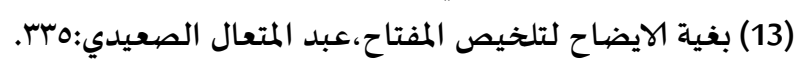

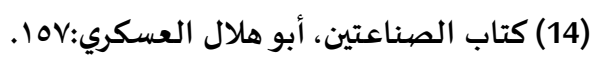

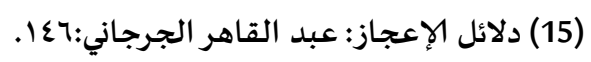

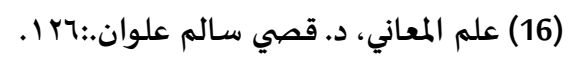

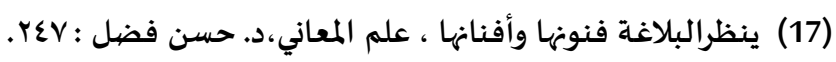

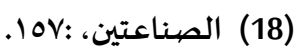


الحذف كثيرة أشار اليها البلاغيون على النص القرآني والشعري ومازوا أهميتها وأكتنهوا الكثير من دلالاتها (·r) ومـن مسوغات الحذف الاقتصاد اللغوي في التركيز على مـاهو ضروري والمشاركة القتية للقارىء حتى لايثعر أنه عاطل الذهن والاستيحاء الفني الأي يفسر الالالات للمتلقي فيحصل

$$
\text { على المتعة (r) }
$$

$$
\text { ـ أنواع أسلوب الحذف الواردةعند الشاعر- }
$$

استعمل الشاعر العبسي أنواع الحذف المتنوعة في شعره وقد قام الباحث بأخذ أسـاليب الحذف التي كـان ظهورهـا في الديوان مشكلا ظـاهرة متكررة تستحق الدرس، وكـان اعتمـاد الباحث في التخريج الشعري للأبيـات مـأخوذا مـن النسخة المحققة للايوان،ونظرة دقيقة على الديوان تكشف اعتماد الشاعر أسلوب الحذف ليكون مجسات قادرة على رصد الدلالة التي يحاول إلقائها أمسام المتلقي الذي يتحاور مع ماغاب منها ليكون متلقيا ومشاركا في الوقت ذاته، وأسـاليب الحذف المطروحة في البحث قد تم اعتمادها على أساس كثرة الورود التي تثكل ظاهرة تستحق الدرس ، وأسـاليب الحذف التي تم درسها عند الشاعر هي:

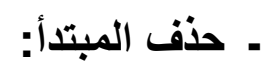

وهـو كثير في الكـلام إذ ((مسن كـلام العـرب حذف المبتـدأ بكثرة وذلتك في جـواب الاستفهام وبعد فـاء الجواب وبعد الخبر صفة لـه في المعنى)(rr(r) ويجوز الحذف فيه إذا دلَّ عليه دليل(rr) وحذفه جوازا أو وجوبا في مواضع معينة(؟r) ولا يتم الحذف وجوبـا أو جوازا إلا بقرينـة دالـة على الحذف وإلا امتتع الحذف فيـ(ro) ويلتفت البلاغيون لحذف المبتدأ فيرجعونـه إلى أسباب عدة منها: صون المسند إليه من أن يذكر باللسان لجلاكة قدره أو لـتحقيره بعدم ذكر أسمه أو للإنكار لأنّ الخبر لايصلح له حقيقة أو إدعاء (r)

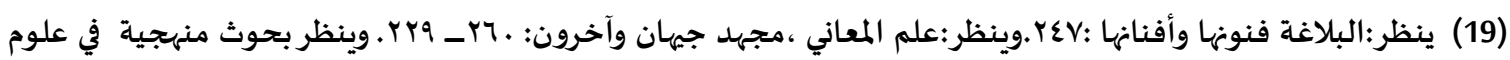

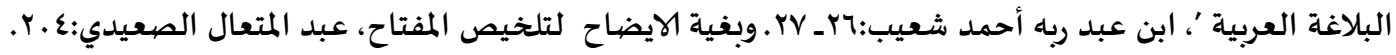

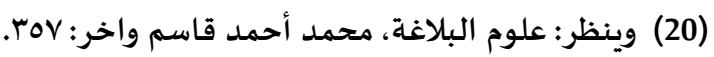

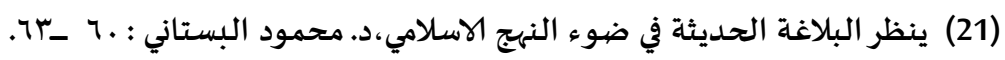

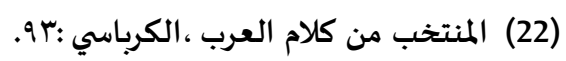

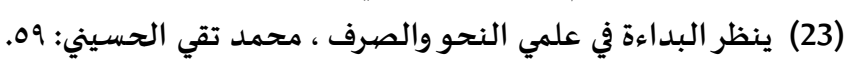

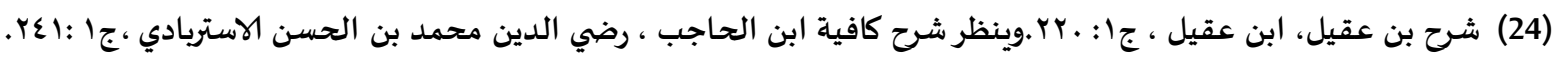

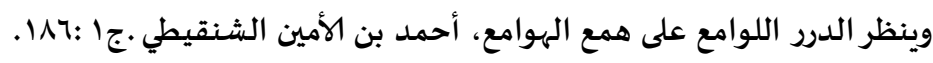

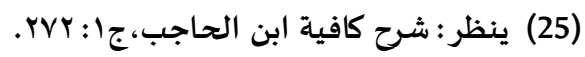

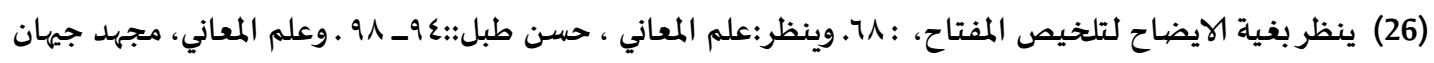

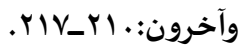


ويأتي حذف المبتدأ عند الشاعر رغبة في المبالغة بالخبر الذي هو صفة تبين ماهية

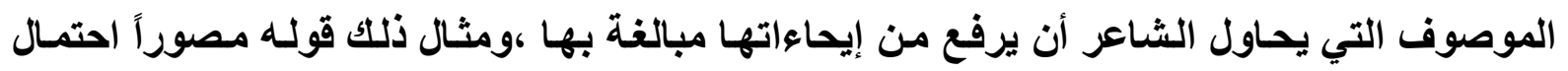

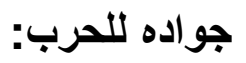

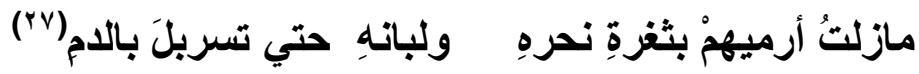

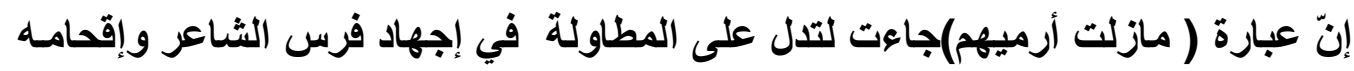

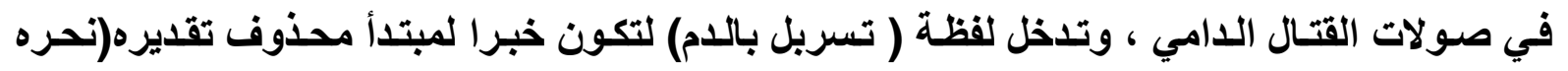

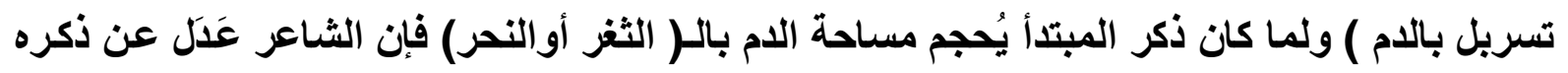

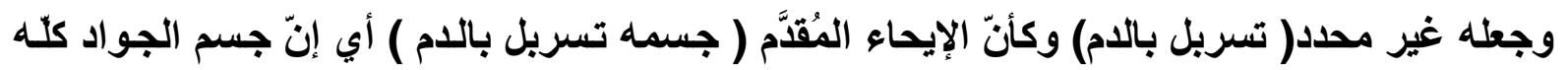

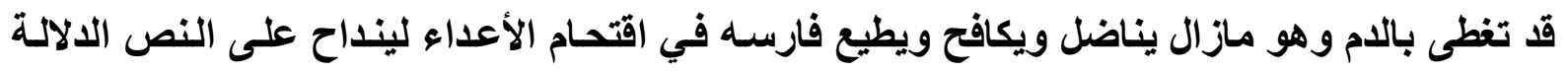
التي توغل في وصف جواد الثاعر وفر ادته. ويحذف المبتدأ وذلك لإكساءَها حالة من التعظيم إلى الشيء المحذوف وهئه ، ويظهر ذلك في وصفه لار الحبيبة التي حاول أكسائها بهالة من التعظيم ، يقول: يادارَ عبلة بالجواءِ تكلمي وعمي صباحاً دارَ عبلة واسلمي

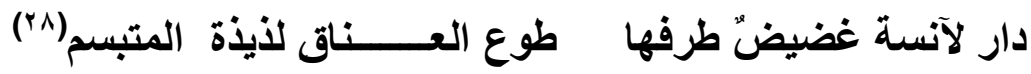

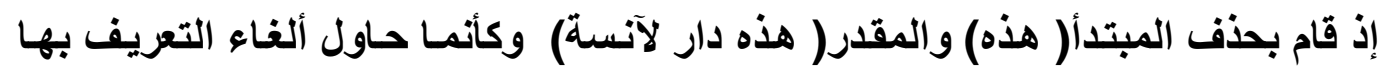

وكأنها شيء مبهم غير خاضع للوصف لأنها عائدة للحبيبة التي هي الأخرى غير خاضعة للمقياس لاس

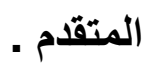

ويأتي حذف المبتدأ عند الثاعر في محاولة منة للتفخيم والتهويل ويكثر ذلك في مواقف

الحرب التي طغت على شعره، يقول:

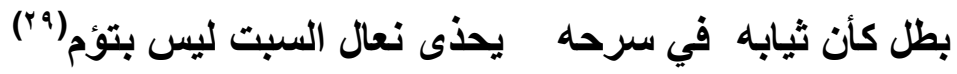

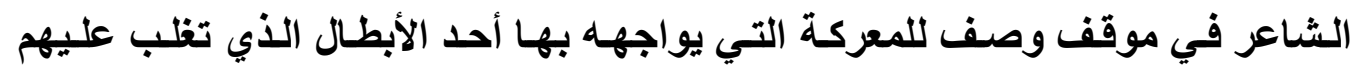

الشاعر ومعلوم أن التفخيم في صسورة الفـارس المواجهـه للشاعر هـوتفخيم لشجاعته وصسورته ،

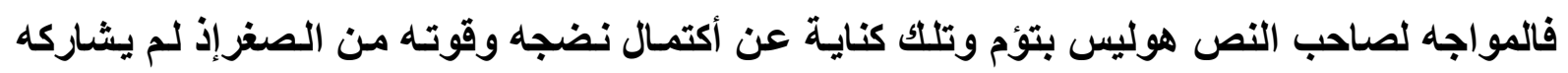

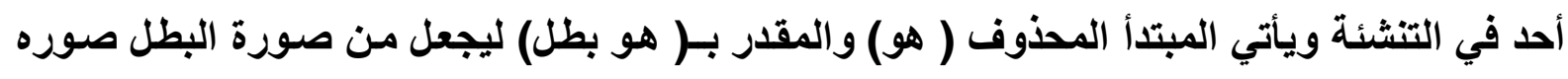

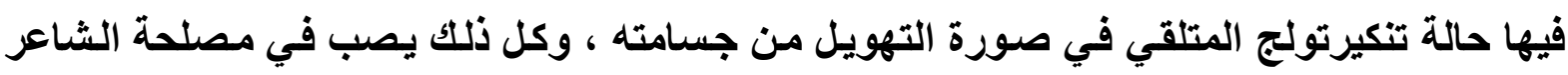
الفارس الثاعر الذي أردا على الرغم من صفاته المتفردة. 
وقـ يكـون وراء حذف المبتـدأ عند الشـاعرأبعاد نفسية أكبر مـن موضـوع التقليل أو

$$
\text { التعظيم ، ومنه قوله في وصف رحلة الأحبة الراحلين: }
$$

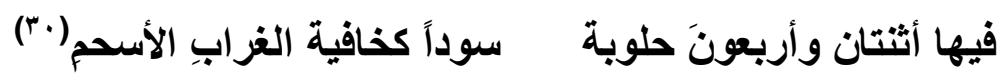

فالثاعر يحذف المبتدأ ( لونها) والمقدر( لونها أسود) وكأن الثاعر بأهماله المبتدأ إنمـا

أراد أن يركز على الصورة اللونية الداكنة(سودا) التي قد تحد من انسيابيتها اللفظة المحذوفة طالمـا أنها مثلت السوداوية والقتامة التي احتوتها نفسه بعد رحيل الأحبـة، بـليل الايغـال في عبـارة( كخافيـة الغزاب الأسحم) التي تزيد الصورة قتامة تشي بما اعتمل في نفس الشاعر المجهة.

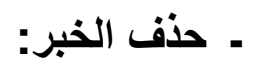

وهـو وارد في كـلام العرب ويحذف (( الخبـر إذا دل عليـه دليـل: جـوازا أو وجوبـا)) ('آ)

ويحفف الخبر(( جوازا نحو خرجت فإذا السبع.. ووجوبا فيما التزم في موضعه غيره نحو لولا علي

لهلك عمر) (rॅ) وحذفه من عادة العرب وله مواضع منها بعد إذ الفجائية وفي جواب الاستفهام (rr) ومنه قول الثاعر:

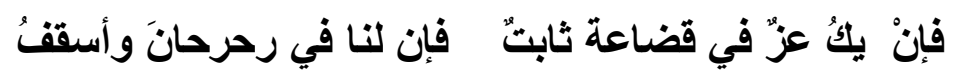

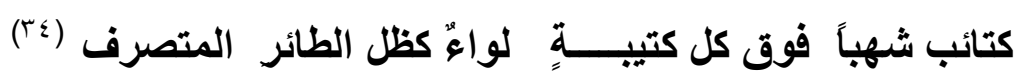

أصلها ( لواء مرفرف كظل الطائر) وإنمـا حذف الخبر ( مرفرف) لإعطاء معنى الثبات

وكأن اللواء الدال على العز ثابت وراكز في الكتيبة لايتحرك ولاينزل إيحاء بالشجاعة والفخار. وقد يحذف الخبر للتهويل وذلك في وصف حالة الحرب:

لما سمعتُ دعاءَ مرة قد علا وابني ربيعة في الغبار الأعلم

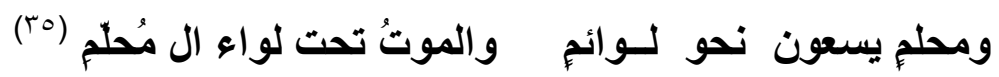

يظهر الشاعر أنه قد أجاب النداء عن طريق الصورة السمعية ( سمعت دعاء) لشدة إجابته للـداعي ثـم تضطرب الصور وتضخم عن طريـق الألفـاظ (الغبـار، يسعون ، المـوت) وتـأتي الصورة الاستعارية للموت وكأنسه كـائن جبار ويحذف الخبر في ( الموت تحت) والمقد ر بـ(الموت واقف أو موجود تحت لواء) ليعطي الصورة التهويلية وكأن الموت بحالة تمساس معهم وتزيد لفظة) تحت لواء) معنى الخطورة التام وكأن الموت تحتهم يحفر لهم قبورهم.

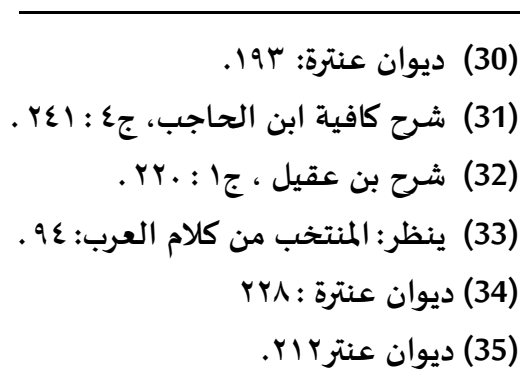


ومن أمثلة حذف الخبر للتفخيم قوله أيضاً:

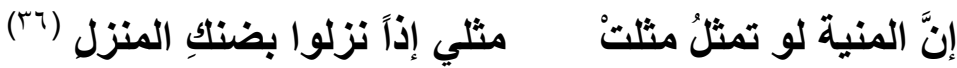

والخبر قد حذف في عبارة( لوتمثل مثلت) والتقدير( لو تمثل مثلت لهم) وتم حذف الخبر ( لهـم) العائد على المبتدأ ( مثلت ) لإعطساء إيحاء أكبر يفخم مـن سطوة الشاعر في الحرب وكـأن الثـاعر في السطوة ممتد في التأثير على الجميع وليس على من خـاطبهم وكأن الإيحاء عـام فالمنيـة الشاعر والثاعر المنية.

ويحذف الخبر لإركاز الشيء الطبيعي الذي يؤمن به الشاعر:

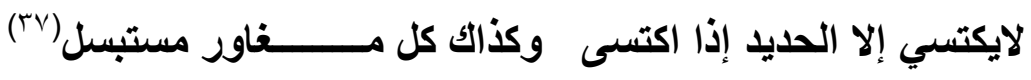
لم يذكر الخبر في(كذاك كل مغاور) والتقدير( كذاك حال كل مغاور )والسبب في ذلك لإعطاء إيحاء بأنّ هذا الحال شيء طبيعي ولاحاجة لذكره. ج ج

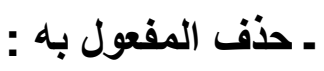

المفعول به هو (( ماوقع عليه فعل الفعل نحو ضرب محمد زيدا)) (^ا)وحذف المفعول

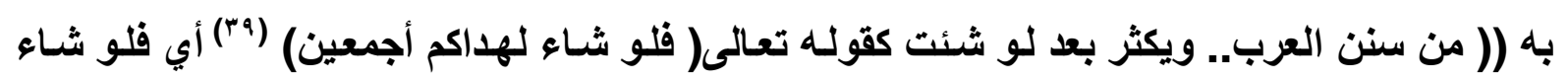
هدايتكم ويحذف المفعول بـه إذا دلت عليه قرينة)) (·؛) والمفعول بـه يحذف لأغراض بلاغيـة منها

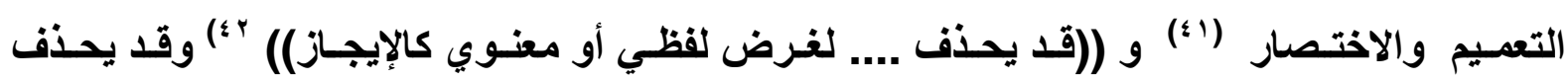
المفعول به ليس لغياب الأهمية في ذكـــــره بـل تكون الغايـة وراءه الرغبـة بإمكانيـة حصوله أو إنــه حاصل ومعروف فلا حاجة لأكره ، ومنه قوله:

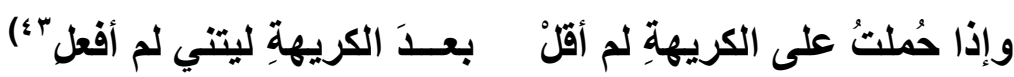
إنّ موقف الشـاعر المعتد بنفسه والمعروف بأفعالـه المجيدة سـاقه إلى شعور راسـخ بأن الإقام على الكريهة هو شيء ثابت في نفسه ولذلك جاءت لفظة (الكريهة) المرتبطة بـالتمني ( ليت ) مقموعة بأداة الجزم والنفي والقلب (لم) التي يمحق أثرها ويدخل الفعل( أفعل ) الذي يخفي وراء المفعول به المقدر (لم أفعل ذلك) ويبدو أن حذف المفعول بـه جاء في إيحاءٍ يعطي فكرة الحاجة إلى ذكر فعل الإقدام الخاص بالشاعر لأنّه معروف.

$$
\begin{aligned}
& \text { (36) ديوان عنترة : دير) }
\end{aligned}
$$

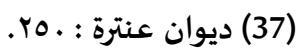

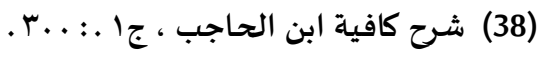

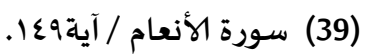

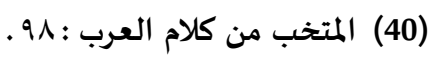

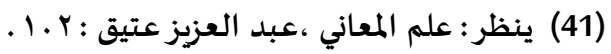

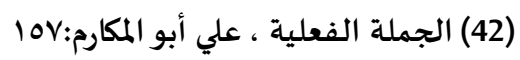


وقد يأتي حذف المفعول به رغبة في رسم إطار مؤثر وقادر على الجذب وإثارة النظر

إلى تأثثر الفاعلية مقابل إهمال مـا كـان من ثأثثر على المفعول بـه إعجابـا بصورة الفاعل أو لإعطاء تأثير أكبر وعام مطلق للفاعل يتعدى المفعول به بمعنى آخر إثبات كمال العناية للفاعل في ذات الفاعل

وحذف المفعول به ((إثبات المعنى في نفسه للشيء على الإطلاق)) (؛ ؛) ومثال ذلك قول الثاعر:

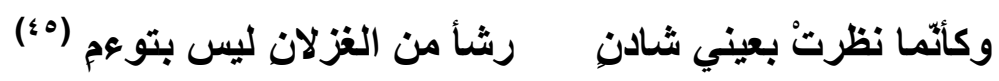

تثقدم الأداة (كأن) في محاولة لتقريب التشبيه متواشجة بالصورة البصرية المتمثلة

بالفعل (نظر) المرتبط بالحبيبة التي طوقت الحيز الوجودي للشاعر وتدخل لفظة (عيني شـادن) قافزة على وجوديـة المفعول بـه الضمير المقدر(نـا) - وأصل العبـارة( نظرتنـا)عائدة على نظرة الحبيبـة للثاعر - ثم مهملة وقعه في محاولة لتركيز صورة تأثير عيون الحبيبة وعمق خطرها من خلال إعطاء هذه النظرة طابع الشمولية والعموم القادر على التأثير على كل من ينظر إليها لتتم عملية تجسيد عمق خطر هذه النظرة ، كما أن الشاعر قد أراد من وراء ذلك التركيزعلى لقت المتلقي إلى

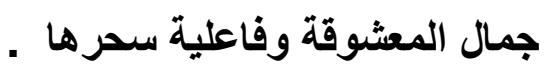

وقد يأتي معنى العمومية عند الشاعر لإظهار صفة الشجاعة ، والمبالغة فيها ، ومنها

قوله في وصف شجاعة ممدوحه:

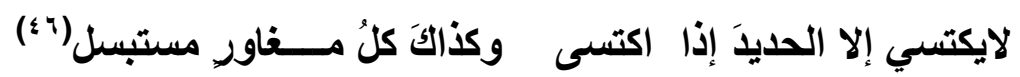

تتقدم ( لا النافيـة ) لترتبط بالفعل المضـارع( يكتسي) الـدال على الاسـتمرارية في

صفات الثجاعة ويختفي المفعول به ( ثوبا ) وتقديره (( لايكتسي ثوبا ألا الحديد) ليحل محلال مفعول به( ثوبا) لفظة ( الحديد ) وتقوم مقامه لتعطي الإيحاء بـالقوة المناطة بممدوح الشاعر وكأن الثياب التي يلبسها الناس للزينة لايعرفها الممدوح فثوبه الحديد في كل الأحوال وفي ذلك عبـارة كنائية تقود إلى صفة الشجاعة المنبثقة من مدوامته على القتال.

وحذف المفعول به عند الثاعر يقوم على توسيع الالالة والمبالغة فيها ،ومنه قوله:

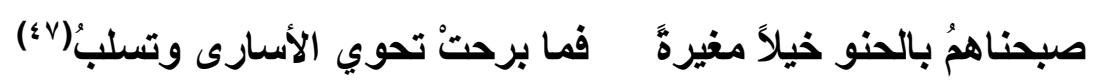

فالشاعر يصور قدوم خيلهم على الأعداء وتظهر علامـات القوة في النص من خـلال

لفظة ( مغيرة ) الدالة على السرعة والقوة ويسطع فعل الخيل الذي هو فعل أصحابها من عبارة ( تحوي الأسارى) التي هي عبارة كنائية عن استسلام الأعداء ويـخل الفعل ( وتسلب) ليختفي وراءه 
المفعول به المحذوف والمقدر ( وتسلب نفوسهم ) ويبدو أن حذف المفعول به ( نفوسهم) قـ وسع من دلاكة فعل الخيل وجعل المفعول به قائم على عدة احتمالات منها( تسلب نفوسهم وأموالهم وكر امتهم... وكل مايملكون....) بمعنى آخر فإن الحذف قد عمل على تعويم الدلالة من خلال جعلها دلالـة مفتوحة وهذا التوسع يفضي إلى المبالغة التي يراد طرحها أمام المتلقي . ويقوم الشاعر بحذف المفعول بـه وذلك لإعطاء إيحـاء بعدم أهميـة الشيء المحذوف وضعف قدره وشأنه وقد ظهر ذلك في هجائه لابنـي ضمضم وتصغيره لشأنهما وفعلهمـا الذي هددا الشاعر به ، يقول الثاعر : الثر

ولقد خشيتُ بأن أموت ولم تلرّ للحرب دائرة على ابني ضضم الشاتمي عرضي ولم اشتمهما والناذرين اذا لم الــــهمها دمي

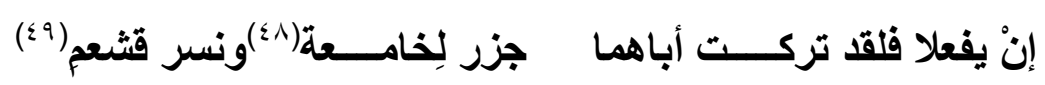

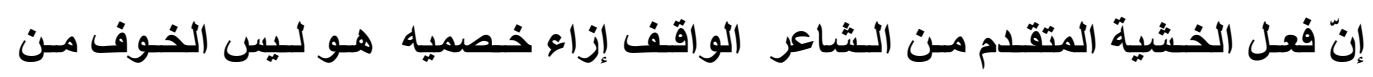
المواجهة بل هو الخوف من عدم تحققها بينها وبينهم لتطفو على النص الدلالـة التي ترفع الشاعر إلى مدارج الثجاعة والغلبة والتمكن ولما كان أعداء الثاعر هم من أصحاب الكلام لا من أصحاب الفعل لأا ترفع عن شتمهم ويـأتي الفعل (يفعلا) المرتبط بالثخصين والخاص بمحاولة قتله فعلاً مستقبلياً غير متحقق ويحذف المفعول بـه (ذلك ) وتقديره ( أن يفعلا ذلك) ليهون من أمر الفعل لمنطلق من أفواه خصومه ولما كـان الفعل غير ذي أهمية وغير وارد في قاموس حيـاة الشاعر ومواقفه البطولية لذا فهو ليس بحاجة إلى الأكر.

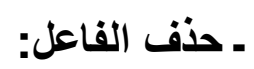

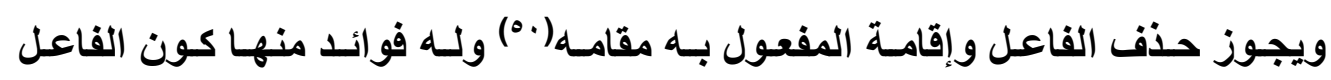

مجهولا رغبة من المتكلم بالإبهام لتعظيم الفاعل(1) وحذف الفاعل لا يقوم الا بقرينة (ro). وقد يأتي حذف الفاعل ليمثل قفزة على واقع الامتداد النحوي - إن صـح التعبير-وهذه القفزة تحول الفعل وقوته إلى شيء هو حالية مستمرة في ذهن الشاعر التي يحاول بثها إلى المتلقي ويظهر ذلك في قوله:

مار اعني الا حمولة أهلها وسط الديار تسفُ حبّ الخمخخم (بهم) 


\section{?}

إنّ الفعل (راعني) قد ألقى بقوة على النص وهذه القوة كان الدافع ورائهـا ايقاع المتلقي في جو من الايحاء نقلته لفظة(حمولة) الملازمسة للفعل( راعني ) المرتبط بالحبيبة ولمـا كانت (( التراكيب تنشىع لنفسها علاقات بليلة في المستوى العميق قد لا تتوافق مـع المستوى السطحي للصياغة))

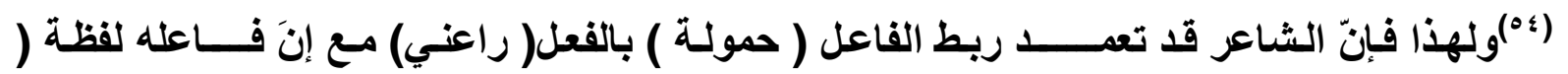
شيء) المحذوفة وذلك لأنَّ القيمة الكبرى التي حملها الفاعل ( حمولة أهلها) قد استوسقت في نفسه فحاول إلقائها على السطح ليبين أثرها الذي ضرب عميقا في نفسه فهي صورة الفراق الأولى. وقد يكون حذف الفاعل دالا على التعظيم عن طريق جعله مُبهمـا ، وهذا الحذف لايأتي لوحده في الدلالــــة بـل يكون السياق العـام قائدا لذلك ورافدا للـــلالة لأن (( القصيدة كل متماسك متكون من أجزاء .... وأي جزء من القصيدة لايمكن أن يؤلف بناءها القني لأن تتآزر فيما بينها)( (00) ومن ذلك قوله:

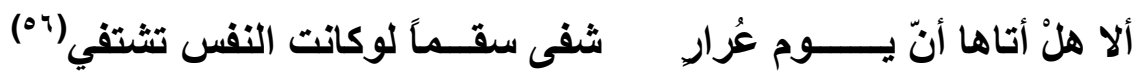
فالسياق العام يقود إلى دلالة التهويل والتعظيم التي حاول الثـاعر طرحها أمسا المتلقي ؛ إذ تثقدم الأداة (ألا ) لتبين حالة من الاستقتاح والتنبيه للطرح المقدم لأهميته ويـخل الاستفهام الذي يخرج إلى التهويـل( هل اتـاهـا) الموجـه لـصاحبة الشاعر والذي يضمر في دواخلـه الخبر المحذوف المقدر ( هل أتاها خبر) ليخرج من خلال حذفه هو الآخر إلى دلالة التعظيم في هذا الخبر الذي تضمن

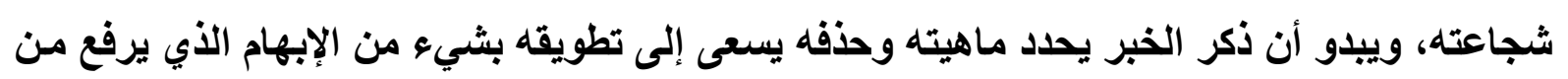

$$
\text { درجة المبالغة فيه وفي أثره. }
$$

وهو الذي يحمل معالم الصفة ((ويجوز حذف المنعوت و إقامة النعت مقامـه إذا دل عليه

دليل نحو قوله تعالى:(أن أعمل سـابغات) ) (ov) وكذا يجوز((يجوز حذف المنعوت إذا كان في الكلام مايدل عليه ويكثر حذفه إذا كان نعته غالبا عليه)) (^م) و(( وأكثر مـايكون في باب النداء نحو يأيها

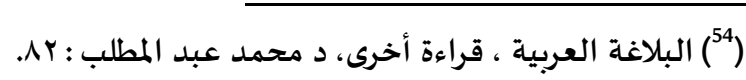

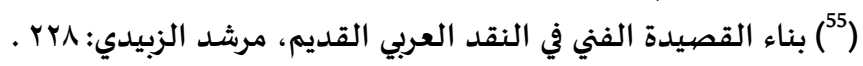

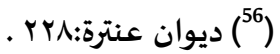

$$
\begin{aligned}
& \text { (57) سورةيوسف /آية وج. }
\end{aligned}
$$

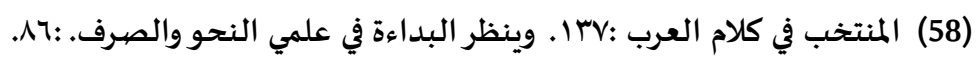


المؤمنون: أي القوم المؤمنون..... وفي باب المصدر مثل قولـه تعـالى(من تـاب وعمل صـالحا ) (99):

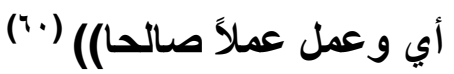
إنَّ حذف الموصوف عند الثاعر هو ليس تغييب لحالته التي قد تتمكن في نفسه بقدر

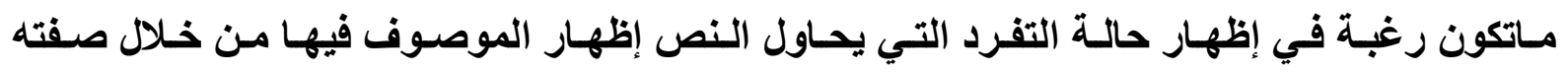
المتميزة إذ إنّ(( حذف الموصوف يتيح للصفة أن تؤدي دورا مزدوجا وهي أن تقوم بمهمتها أولا ثم

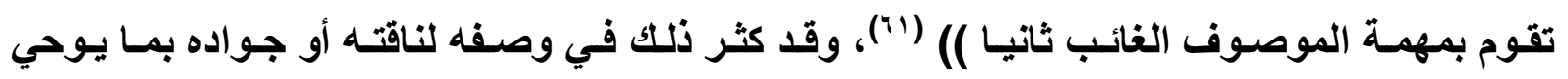
تفردهما بتفرد الراكب عليهما، يقول الثاعر في حواريته مع الحبيبة مارا بذكر جواده :

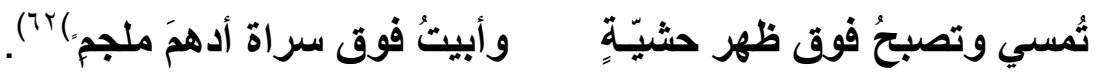

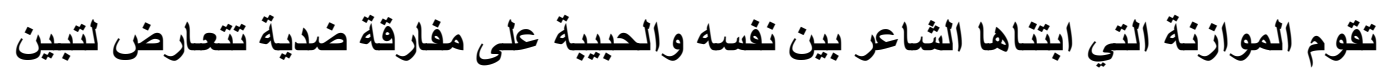

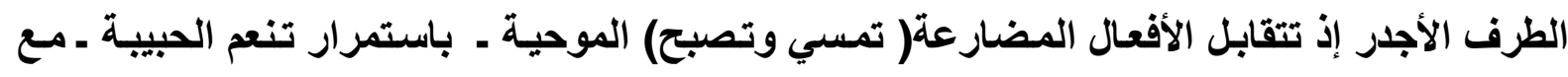

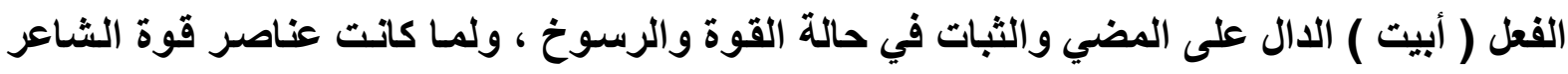

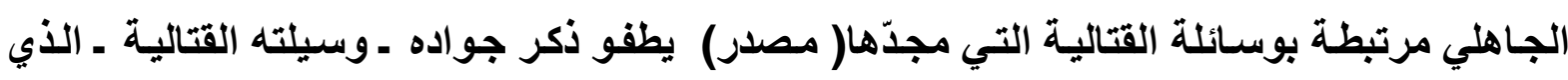

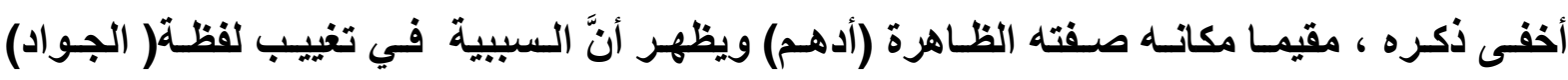
والاكتفاء بذكر صفتة كانت مقصودة من الشاعر رغبة بإسدال وإكساء وسيلته الحربية حلة من الفخار من خلال تميزه عن باقي الجياد وكأنّ لفظة ( أدهم ) الدالة على القوة والتفرد هي الاسم الذي أصبح

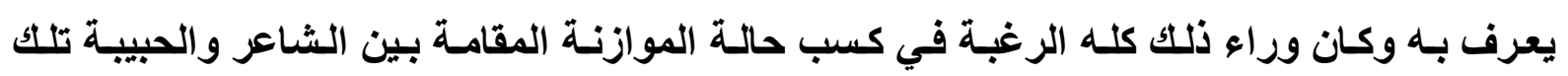
الموازنة التي أغبقت الفارس الشاعر بصفات لايمكن للحبية الارتقاء إليها.

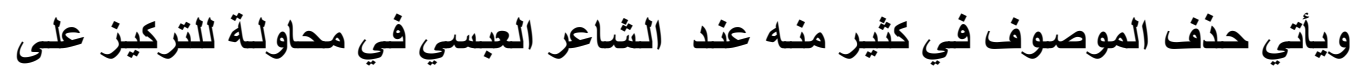
صفته التي تعلي من شـأنه الأمر الذي يطلي من شـأن الشاعر الذي يعد وسيلة من وسـائله التي توصله إلى الذرى والمجد ، ومنه قولئه

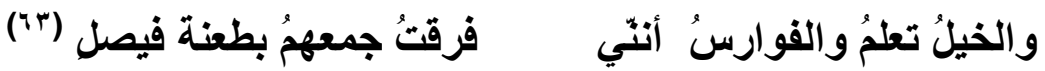

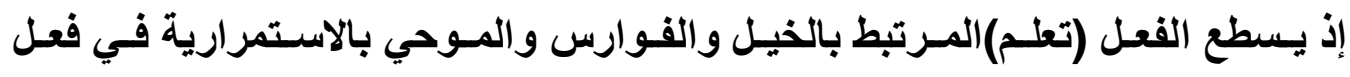

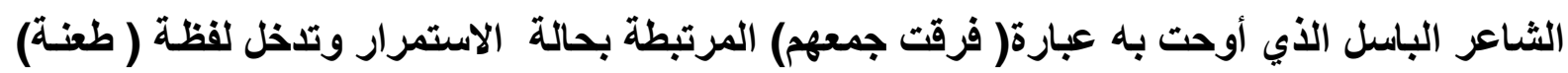

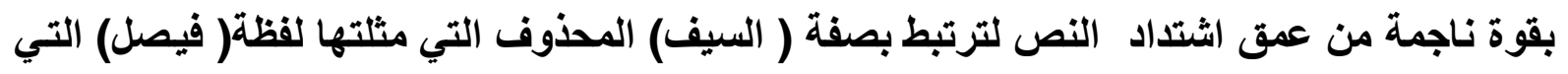

$$
\text { (59) سورة الفرقان/ آية م . }
$$

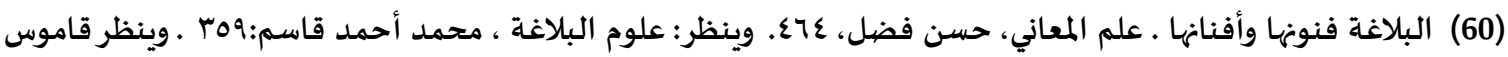

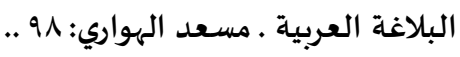

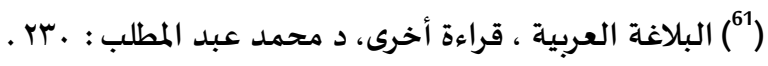


تزيح ماهية سيف الفـارس الشاعر عن السيوف الأخرى وكأن الصفة التي أتت حاملة للقوة قد أصبحت هي المسمى التي يعرف به سيف صـاحب النص ، وبهذا فإن الإعلاء من قيمة عدة الشاعر

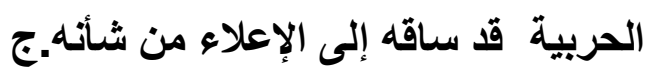

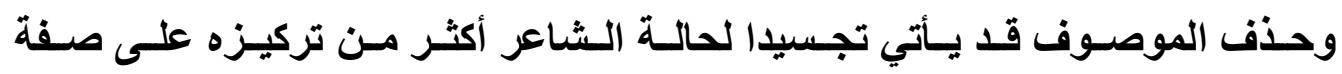
الموصوف وتغيبه لأنّ الصفة راكزة في عمق نفس صـاحب النص كما في وصفه وقوفه على ديار

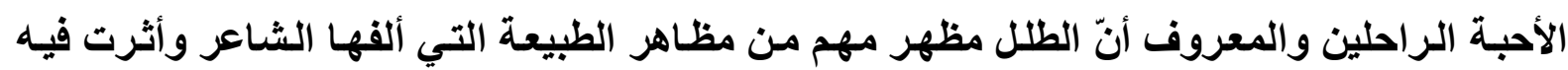

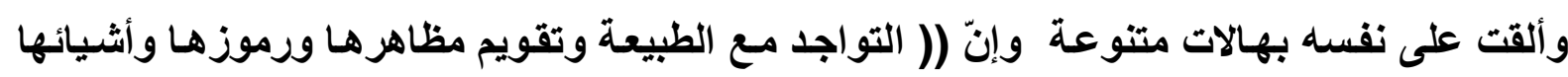

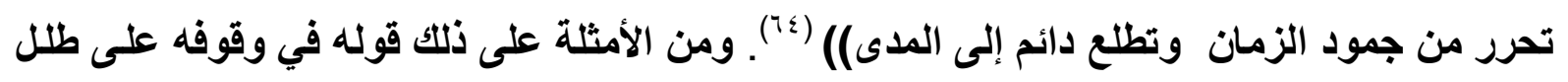
الحبية الدارس: من جمود العز

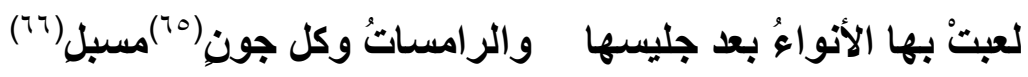

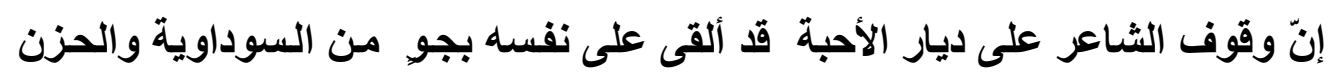

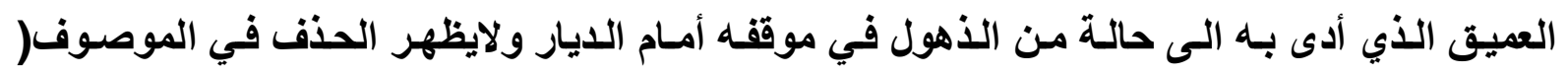

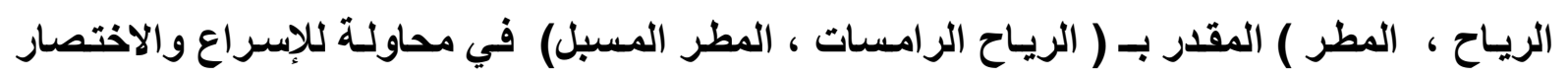
ولمـا كانت ((روح الشاعر ومـا يعتمل في ذاته من انفعالات وأحاسيس وروئية ووجدان ومشثاعر...

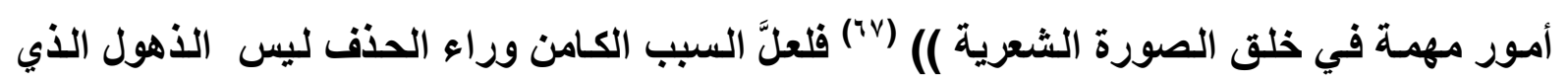

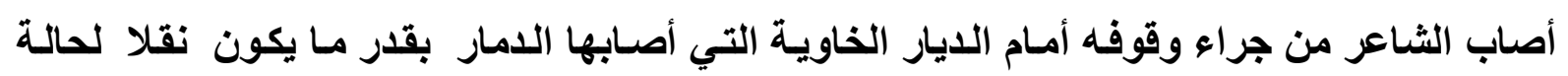

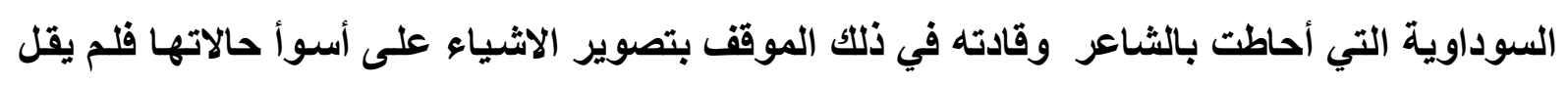

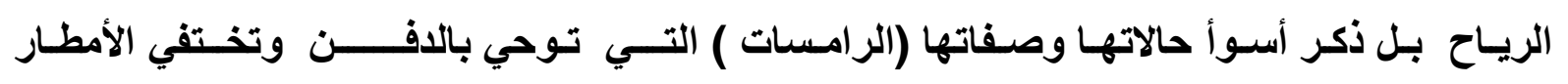

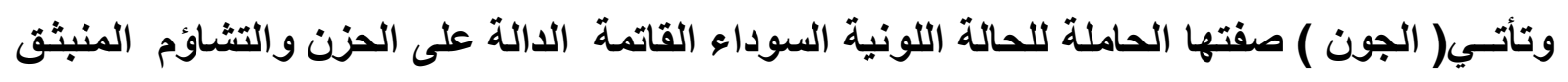

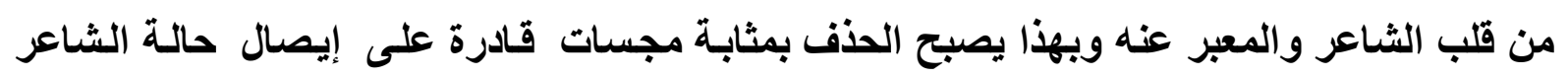
إلى المتلقي والقطيعة والتفرق والتمزق العائدة على الثاعر بالحزن وخيبة الأمل.

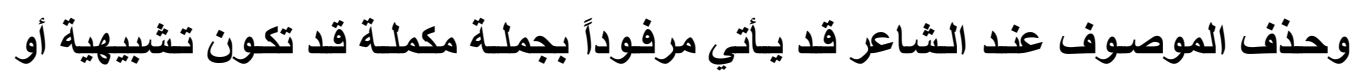

استعارية تعمل على الإحاطة بالدلالة التي يراد طرحها من خلال الحذف ، ويظهر ذلك في قوله:

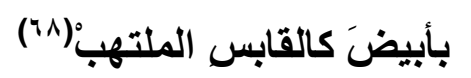
تداركَ لايتقي نفسهُ 
إذ يـخل الفعل (تدارك)ليدل على السرعة القائمسة عند الممدوح الشجاع الذي تـأتي عبارة ( لايتقي نفسه ) مُشكّلة عبارة رمزية محيطة بالشاعر الفارس موحية بحالة الإقدام والشجاعة لاية و وتلخل لفظة ( أبيض) صفة للموصوف المحذوف(السيف ) المقدر بـ( سيف أبيض ) لتسطع من خلالها الصورة اللونية الدالة على الوضوح والإنكشاف في فعل السيف ـ الذي هو فعل الشاعر ـ وتـخل الصورة التشبيهية المكملـة لصورة السيف ( كسالقبس الملتهب) فضضلا عن حالـة الوضسوح والانكشاف في فعل السيف التي يتم إظهارهـا على حساب حذف الموصوف ثُكمل الصورة التشبيهية المعالم الأخرى لله من خلال تبين حالة الثدة والقوة فيه.

$$
\text { ـ حذف المضاف اليه : }
$$

المضاف اليه(( كل اسم نسب إلى شيء بواسطة حرف جر لفظا أو تقديرا مرادا)) (99)

$$
\text { ويحذف المضاف من الجملة إذا وجد المضاف إليه الذي يستدل به عليه(v) }
$$

وقد يحذف الشاعر المضاف اليـه لإعطاء إيحاء بأهميـة الشيء وولوجه و واندماجه في

نفسه، ومنه قوله:

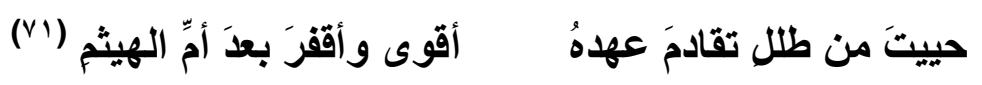

إذ تثقدم عبـارة ( حييت ) كعلامسة استبشار مرتبطة بطل المعشوقة ( رمز الاستبقاء)

وتأتي الأفعال ( تقادم ،أقوى ، أقفر) كعلامـات توحي بالحزن القابع في نفس الشاعر والمعروف أن

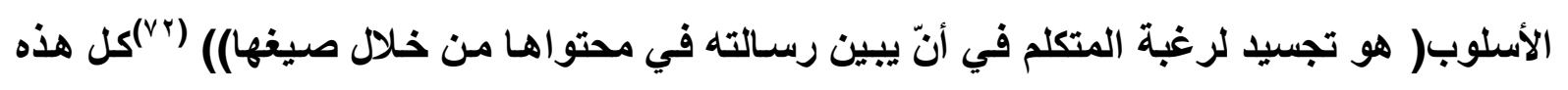

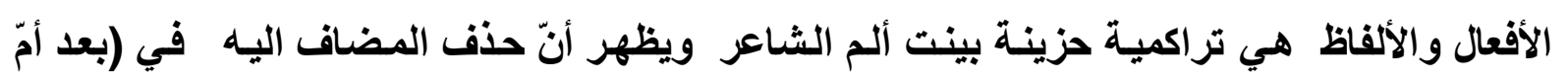

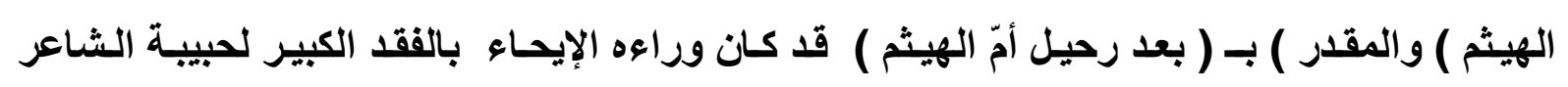
ولهذا فإنّ لفظة الرحيل تختفي وتنزاح وتبقى الحبية ( أمّ الهيثم ) راسخة في نفس الشاعر رافضة لكل تحولات الفراق والبعد ذلك أنها استوطنت في نفسه المحبة للحبيبة الراحلة. وقد يحذف الشـاعر المضاف والمضاف إليـه لإعطاء معنى العموميـة والشمول ، ومنـه

قوله:

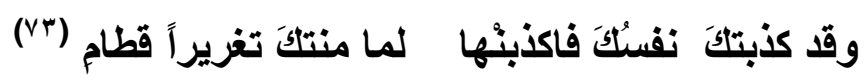

إنّ نفس الشاعر قد منته بوصل من الحبيبةة قطام) ولمّا كاتت أماتيهـا أكاذيب أوقعت

الثاعر في الأسى فما كان منه إلا أن يرفض كل شـيء منها ولذا جـاء حذف المضاف والمضاف إليه

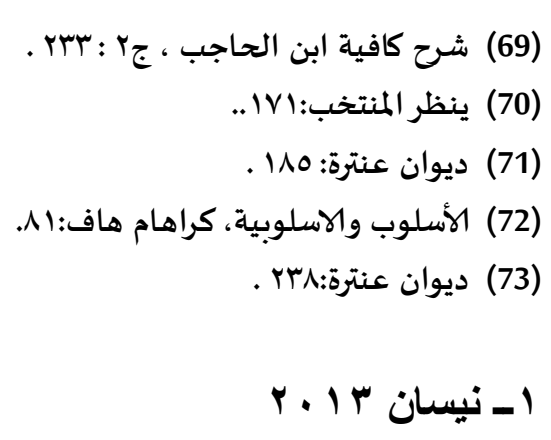


والتقدير( فأكذبها بعد اليوم أو فأكذبها في كل حين) والإيحاء هنـا يعطي الإطلاق والعموميـة ( أي

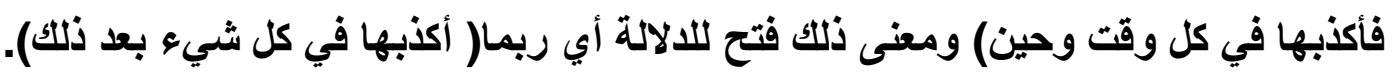

وقد يحذف الاسم خوفا من التكراركما في قول الثاعر:

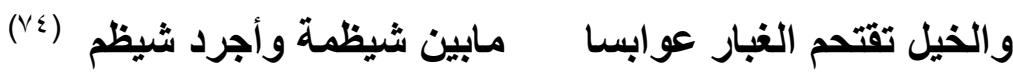

فأصل العبارة( مابين شيظمة وبين أجرد شيظم) فحذف لفظة ( بين) خوفا من التكر ار.

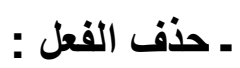

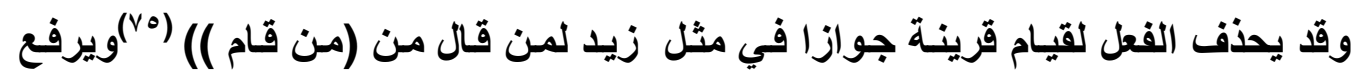

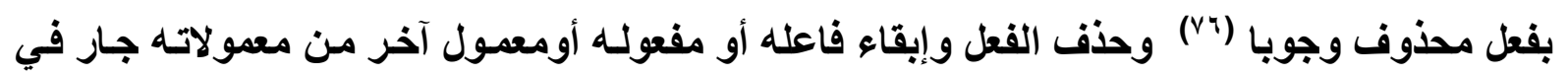

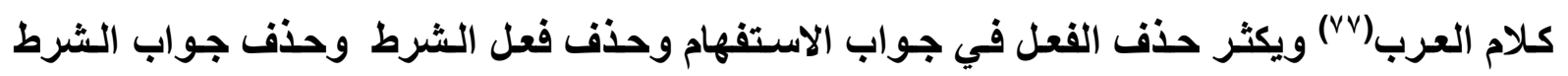

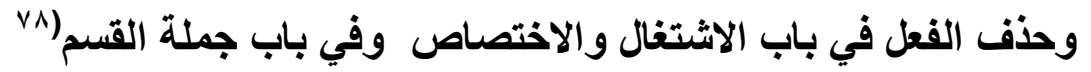

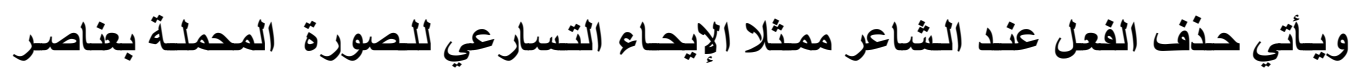

القوة كما في وصفه للناقة الهادرة الخطوات والممتلئة قوة ونثاطا، يقول:

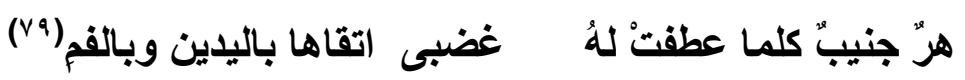
إنّ محاولة تصوير قوة ناقة الشاعر واندفاعها في القلوات سـاقه إلى استجلاب صورة من مخيلته مصورة انعطافها في سرعة وقوة إلى اليمين واليسار وكأن وراء سـاقيها هر وحشي التهي

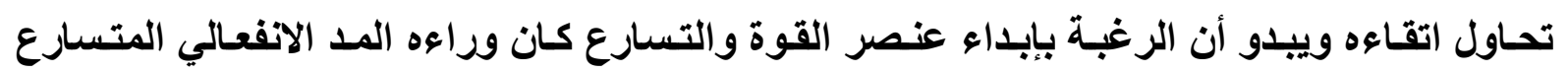
المتواصل المتوازي مع تسارع ناقة الشاعر الأمر الذي أدى إلى حذف الفعل( اتقاهـا) المقدر( أتقاهـا باليدين (واتقاها) بالفم). وحذف الأفعال عند عنترة لـه دلالات متنوعة لأنّ الحذف في الأفعال لهه دور كبير في

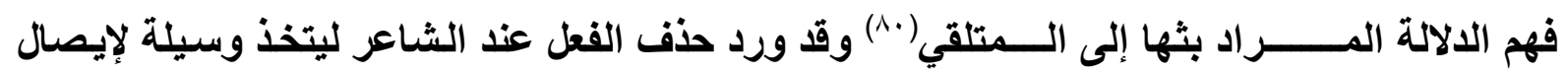
الدلالات التي يراد بثها إلى المتلقي وقد يحذف الفعل عنده لضرورة الاشتراك فيه' ومنه قوله:

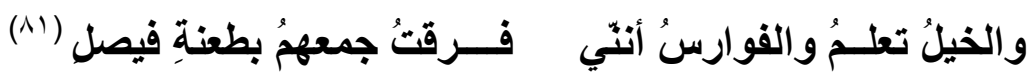

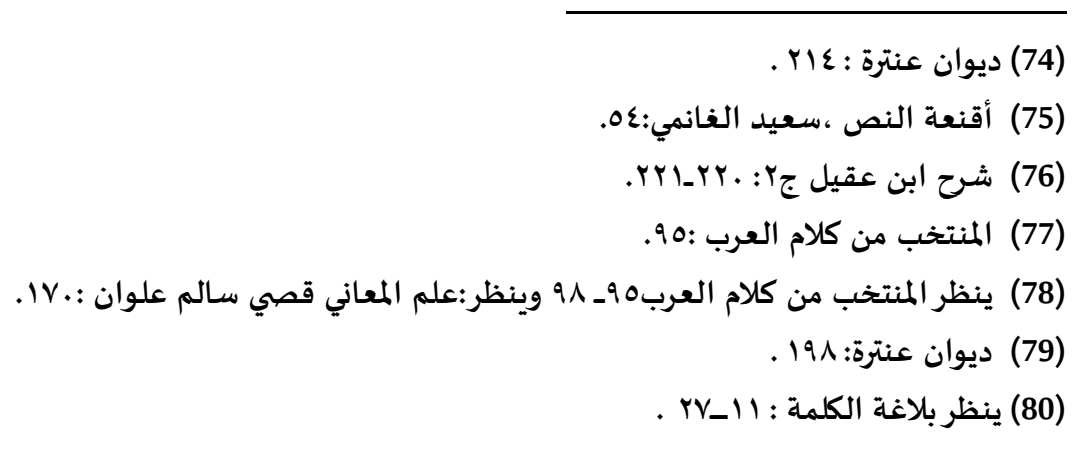


فلم يقل (الخيل تعلم والفوارس تعلم) وحذف الفعل تعلم فقـال( الخيل تعلم والفوارس) فكأنه لافاصل بين الفوارس والخيل، لأنها تمثل ماهية واحدة. ويحذف الفعل وذلك لإعطاء إيحاء بالمبالغة والثمولية فيها وهذا من ميزات وانه حذف ونف

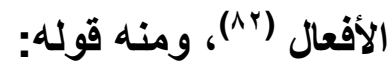

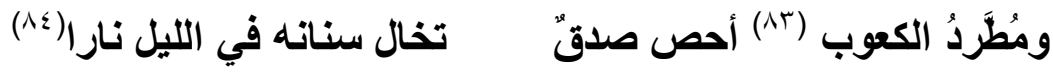

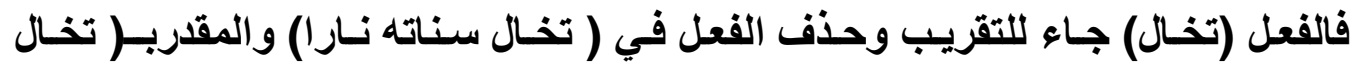
سناته تثتعل في الليل نارا) لإعطاء معنى المبالغة فسناته كلها نار أوشبه ر رمحه في توهجه في الليل

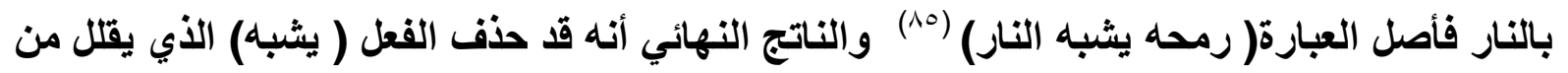
الفارق الذي يثيره الفعل التثبيهي بين المتقابلين ومعروف أن حذف اداة التثبيه ـ التي قد تأتي فعلا ـ

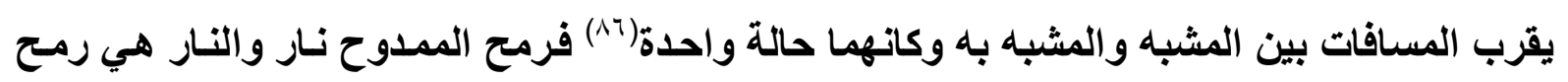
المدوح وهذه النتيجة لاتختلف عن الطرح الأول المقدم. وقد يقوم الشاعر بحذف الفعل والموصوف ليعملا معـا في إيصال الدلالـة التي يحاول

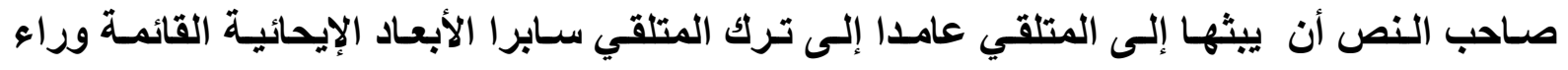

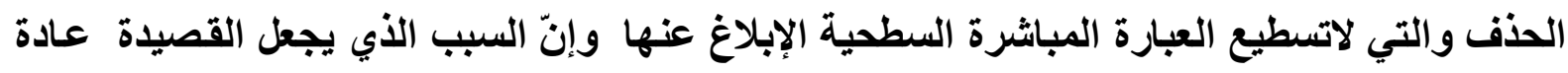

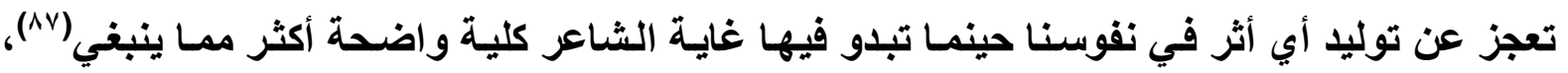
ومنه قوله واصفا وقوفه مراقبا قافلة الأحبة الراحلين:

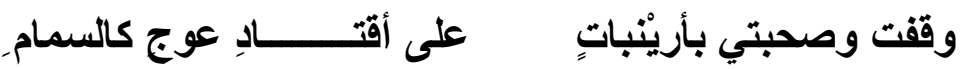

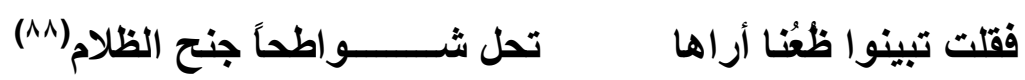
يتقدم الفعل (وقف) العائد على الثاعر موحيا بالتأبيد والقدم في الانتظار ثم لايلبث أن

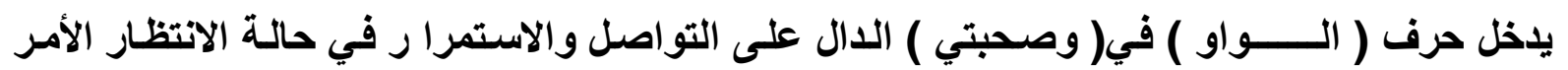

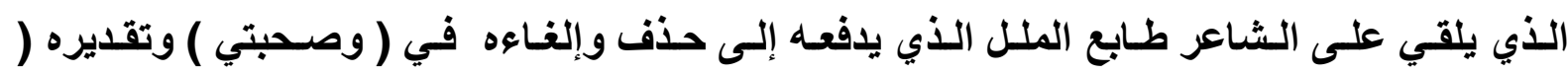

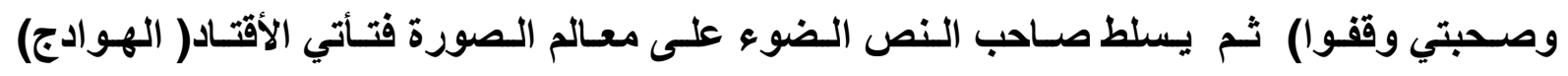
المحمولة على الجمال بيد أن الثاعر يسهم إلى إخفاء ذكر الموصوف ( الجمال ) في محاولنة للتركيز 
على صفتها( عوج) الموحية بالنحول المستشرف لوقوع الشاعر في دائرة الإعياء ثم يلخل الإيغال

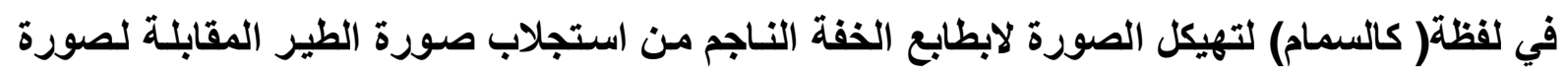

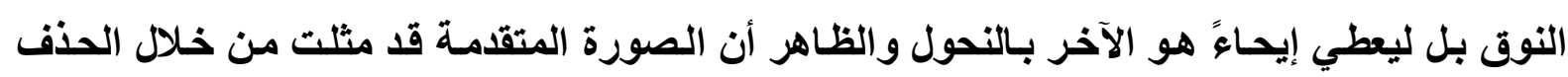

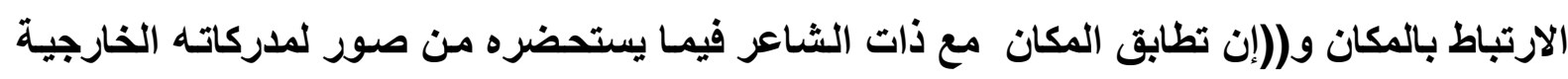

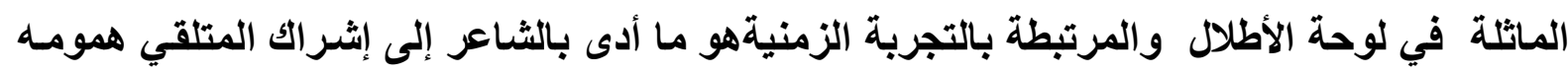

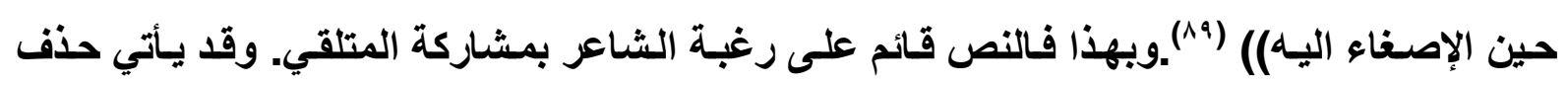

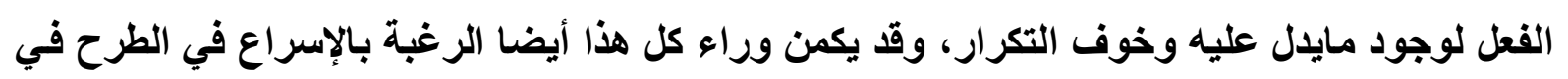
موقف من المواقف، ومن قوله :

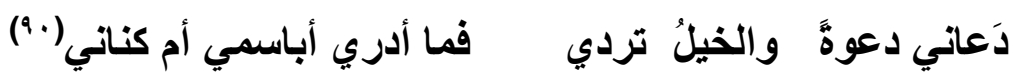

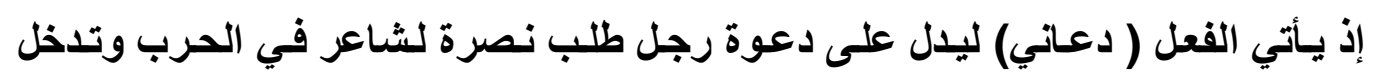

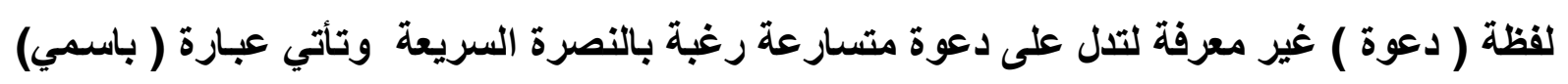

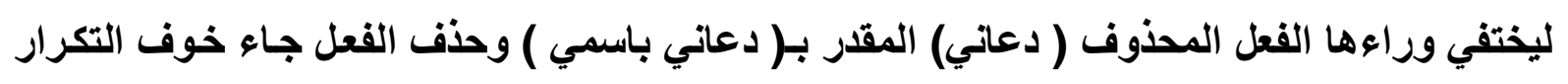

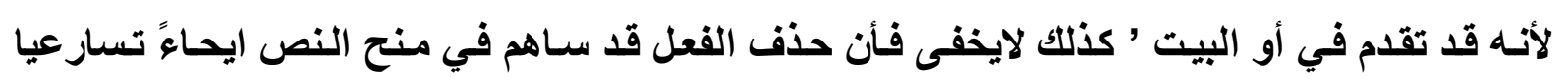

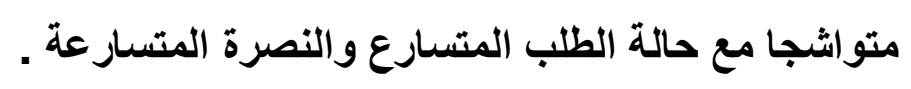
- 2 حذف الجملة:

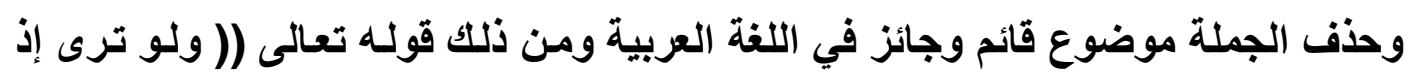

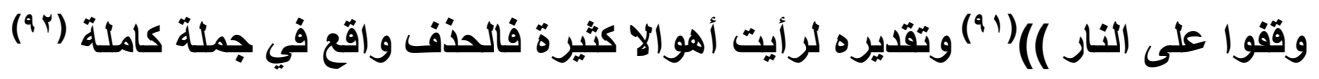

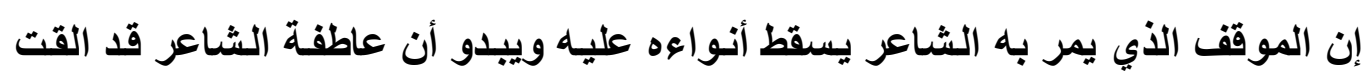

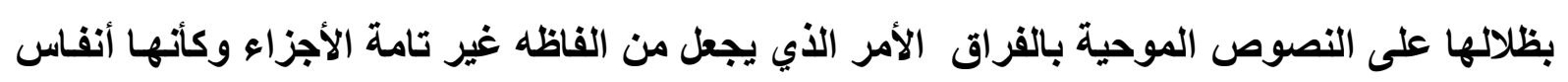

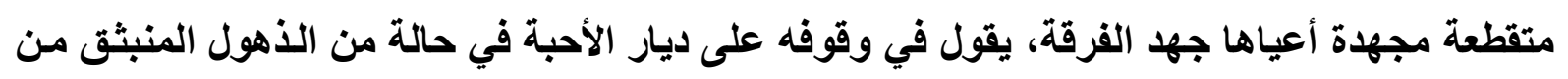

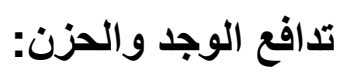

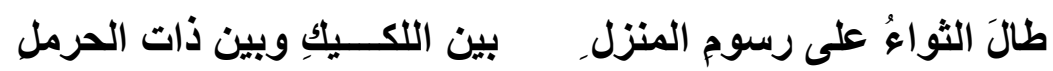

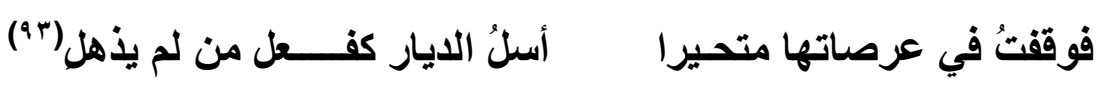

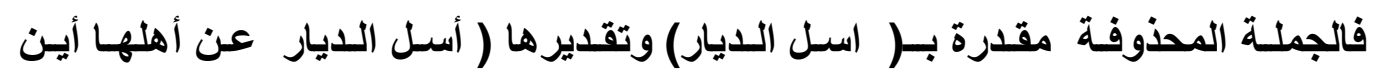

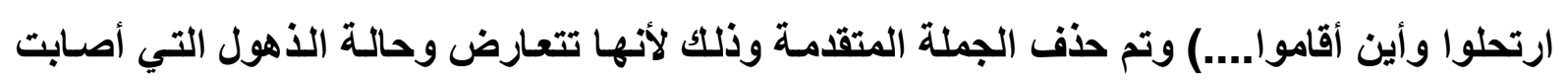

$$
\begin{aligned}
& \text { (89): الاتجاه النفسي في نقد الشعر العربي، عبد القادر فيدوح:هع؟. }
\end{aligned}
$$

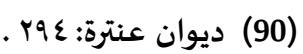

$$
\begin{aligned}
& \text { (91) سورة أانعام/ آية } 7 .
\end{aligned}
$$

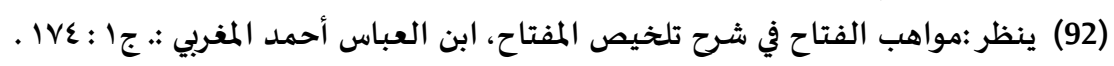

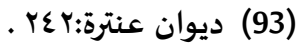


الشـاعر جراء وقوفه على ديـار الأحبة الخاويـة، لذا كاتـ الألفـاظ المطروحة أشبه بالمجسات التي تجوس أنفاسه المتقطعة .

ويعل الحذف بين شيئين الانحراف وكسر النظام الطبيعي إذ (( يجمع البنـائيون على إن أهم العناصر الخاصـة بـالقول الجمـالي هو أن يكسر نظـام الإمكنـات اللغويـة الذي يهدف إلى نقل المعاني العادية ويهدف هذا الكسر بالذات إلى زيادة الدلالات الممكنة) (؛وج) وقد يأتي حذف الجملة ليكون الجواب المتسارع عن حالـة الذهول أو الاستغراب التي تطرح أمام الثاعر في مواقف معينة ، ومنه قوله مخاطبا الحبيبة التي تعجبت من نحوله:

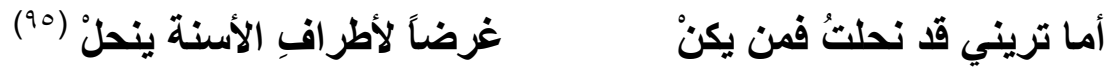
فالشاعر يرفض الاستغراب الأي قامت بتوجيهـه الحبيبة من شدة نحولـه فجـاء الجواب متسار عا بحذف الجملة من(إمّا تريني قد نحلت) والمحذوف بعدها (إمـا ترينـي فلا تتعجبي من مظهر النحول الذي لف جسمي وجعله غير جذاب.....) لأنسه يريـ الـخول مباشرة للجواب بهدف رفض الاستغزاب المتقدم بحالة من الفخر تقوم على إركاز صفة الثجاعة بالشاعر. وتحذف الجملة ليس لغياب أهميتها بل قد تكون في غايـة الأهمية بيد إن الغيـة المبتغاة من وراء الحذف التحفير والتببيه على ضرورة الالتفات إلى المحذوف من قبل المخاطب، ومنـه قوله ، مخاطبا الحبيبة، ومفتخرا بنفسه:

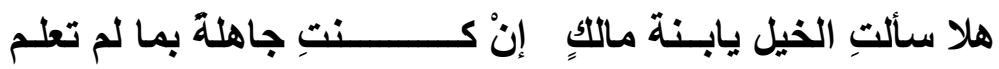

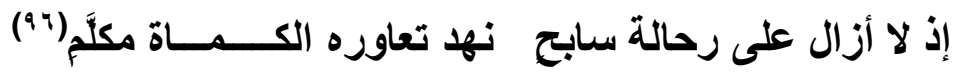
يتقدم الاستفهام قويـا هـادرا للإصحاء ويأتي بعده النداء ( يابنـة مالك) رغبة بالصحو التام من الحبيبة لأهمية الطرح الذي سوف يطرحه الشاعر ويأتي طلبه منها بالسؤال عما يفعله في الحرب محيرا لأول مـرة( هـلا سـألت الخيـل) والمحذوف وراء الجملـة مقدربـ( هلاسـألت عن أفعالي وصبري وشجاعتي فتخبري بكل الثهامة......)ويبدو أن الثـاعر يحس أن الذي يستحق أن يقال عنه كثيـر ولاتكفيـه العبـارة إضـافة إلى طـابع التحفيز الـذي خلق عنــ الحبيبـة مـن خـلال رغبـة المعرفـة المخفية. وقد تحذف الجملة عند الثاعر لأنها لاتستوعب المد الاتفعـالي المتصاعد عند الشاعر ، ومنه قوله في حالة شد نفسي : ألا قاتلَ الله الطلولَ البـــواليا وقاتـــــــــلَ ذكراتك السنين الخواليا 


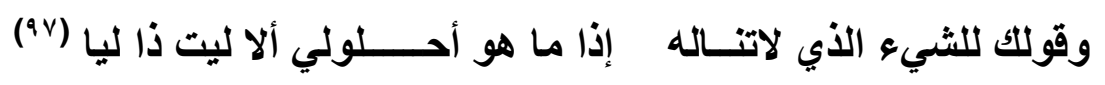

فالشاعرفي وقوفه الطويل على الطلل يشعر بغيـاب النفعيـة من وراء ذلك الوقوف

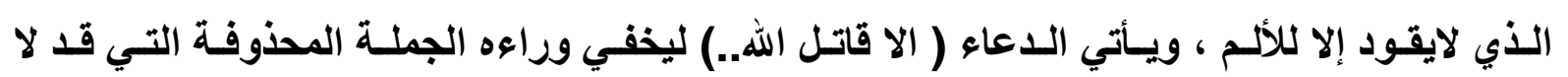
يستوعبها البيت الشعري لأنها إرهاصات لنفس صاحب النص طال أمدها والتي يمكن تقديرها ب( قاتل الله الطلـول مأجلبهـا للأحزان .. لاخير ورائهـا الا الألــ...) وكذلك الحـال في عبـارة ( وقاتل ذكراك السنين الخواليا ) التي تحمل المضمون المتقدم . وقيكون وراء حذف الجملة الرغبة بالمحافظة على إثراقية الصورة ويكون الحذف عند الثاعر قائما وراء الجملة الكنائية التي لها قدرة على استيعاب المشاهد المحذوفة وبسط أثرها ، ويظهر ذلك في قوله:

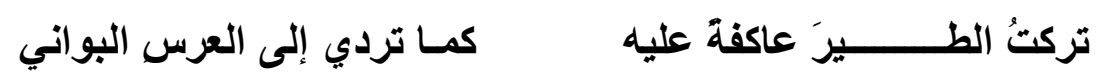

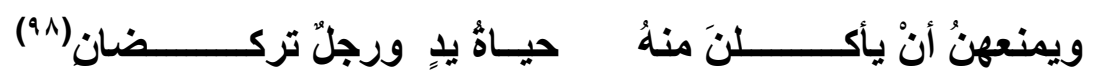
فعبارة ( عاكفة عليه) عبارة دالة على مقتل عدو الشاعر وإذلاله من خلال جعل الطيور آكلة تثهش من لحمه في كل وقت وحن وكأنْ لاحامي لـه ولاراردع أمسام الفـارس الشـاعر. ويظهر أن الثاعر قد قام بحذف الجملة القائمة في مستوى العبارة العميق( عاكفة تأكل من لحمـه في كل وقت) والبين أن الثاعر قد لون الصورة المتقدمة مع إنها صورة حرب ( فالطيور أثبه بالنساء التي تصفق في عرس. ولهذا فحالـة الانهزام ومـوت عدو الشاعر هي حالة فرح مشرق وقد جـاء حذف الجملة ليحافظ على إشراقية الصورة مع قدرة الجملة الكنائية على استيعاب ـالمشاهد المحذوفة. ـ حذف أداة النداء:

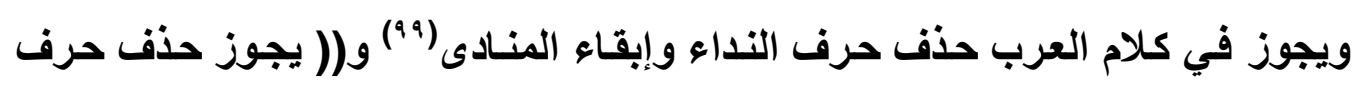

النداء مع اسم الجنس والإشارة والمستغاث والمندوب نحو : ((يوسف أعرض عن هذا )) (“')" وأيها الرجل وشذ أصبح ليل)) (1+1) وشرط الحذف أنه دل عليه دليل(r+1) له فاعلية في شعرية النص وذلك لأن الثاعر يخلق الأت التي يخاطبها بحيث يرتهن وجودها بالنداء فالنداء هنا يحتضن الذات التي تخاطب وللنداء أثز مهم في الدلالة .

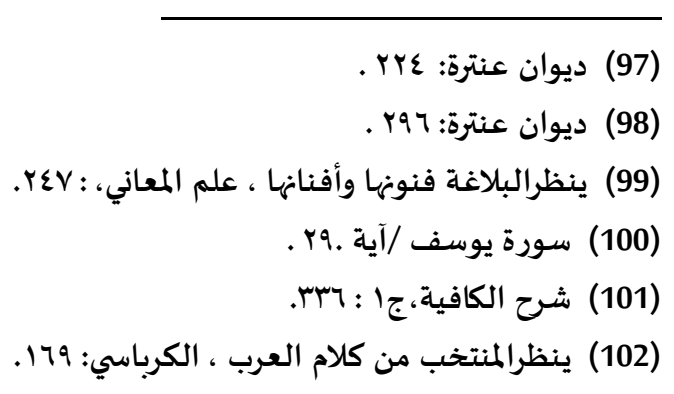


ويسأتي حذف أداة النـداء فـي محاولـة للإصـحاء والتتبيـه أو المخاطبـة الموجهة مـن

الشاعر إلى شيء مهز ويظهر ذلك في مخاطبته الحبية الراحلة، يقول:

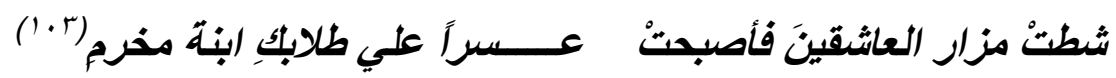

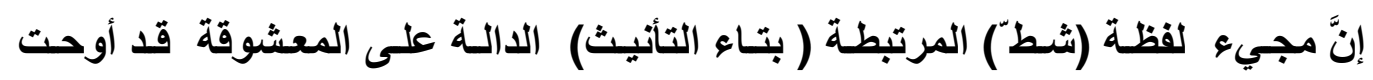

بالبعد الروحي الموشي بالفقدان ويأتي الرفد في لفظة ( عسرا ) المرتبطة (بطلاب المعشوقة )

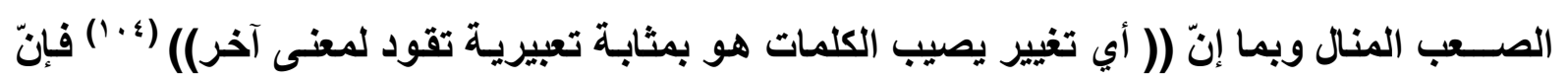

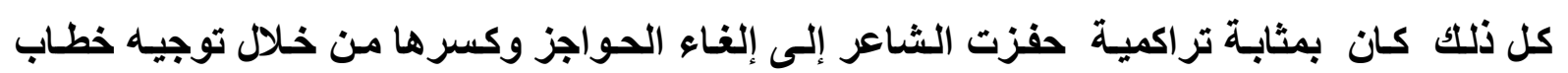

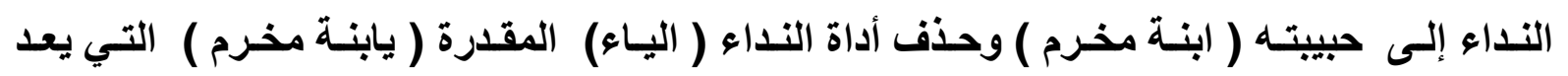

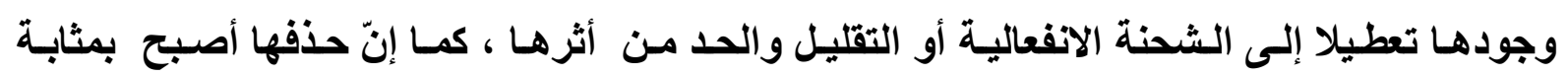

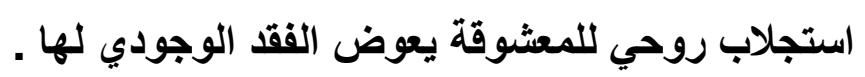

ويرد حذف أداة النداء عند الشاعر العبسي وذلتك لإعطـاء الإيحساء بالمسارعة أولإ. ظهار دلالات أخرى ومن ذلك قوله:

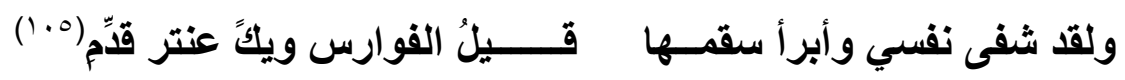

النص ينقل إلى المتلقي الأجواء الحربية التي خاضها الشـاعر الفـارس التي تحساول

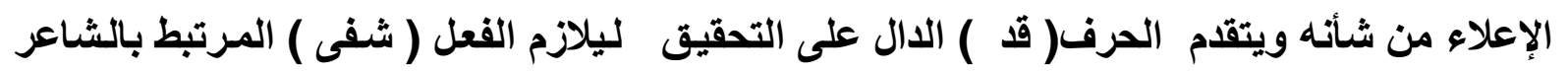

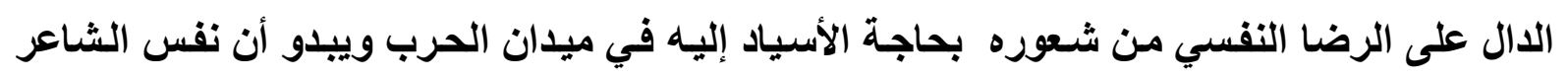

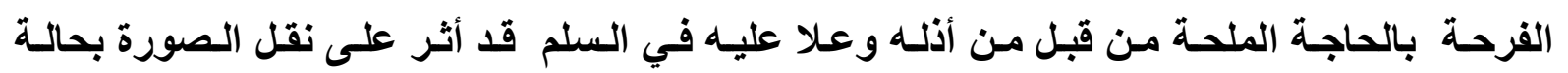

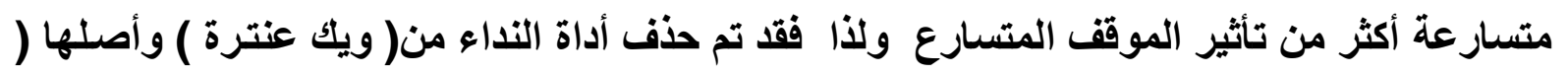

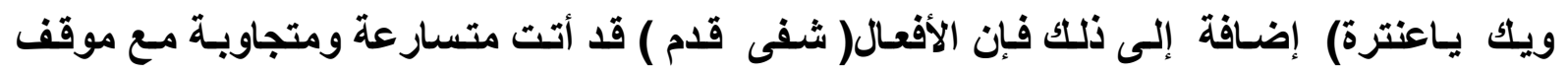
الحرب المتسارع وموقف نفسه التي تطوحت في جو من الخيلاء الذي قاده إلى الافتخار.

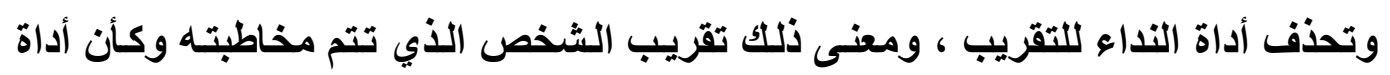

النداء تصبح بمثابة عازل بين الطرفين،ومنه قوله:

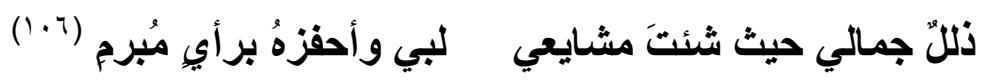

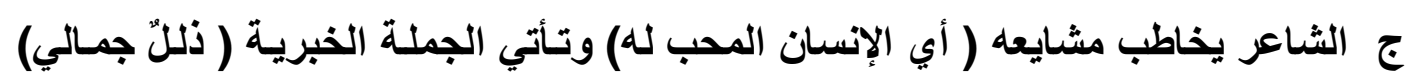

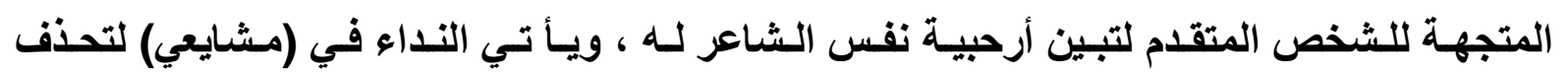


منه(أداة النداء) وأصلها( يامشايعي ) لتدل على حالة القرب بين الاثنين التي أدت بالشاعر إلى تذليل نفسه له.

ويأتي حذف النداء عند الشـاعر العبسي في محاولـة للتقليل من شـأن المخاطب ومنـهـ

قوله في مخاطبة حبيتة (عبلة )التي أقلت من شأنه فعيرته بنسبه:

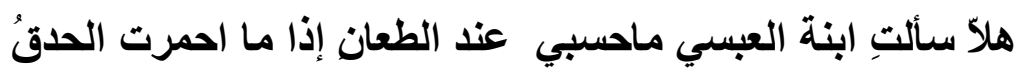

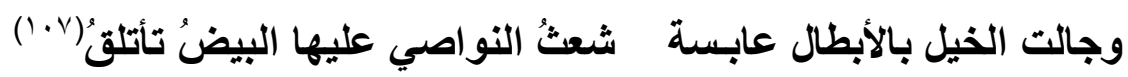

إذ تتقدم عبارة (هلا سـألت )الموجهة لحبيبة الثاعر ـ التي صعّدت من انفعاله لأنها عيرته بنسبه ـ قوية دالة على الرفض العالي حاملة في دواخلها ضرورة الالتفات إلى الطرح المقدام

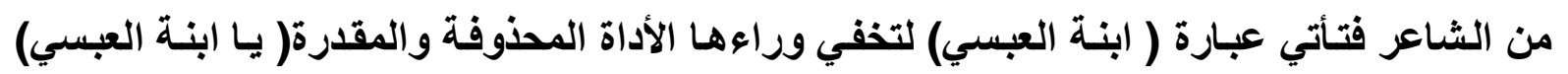
والالالة القابعة وراء الحذف هي التقليل من شأن صاحبته و والظاهر من خلال عدم ذكر اسمها واسم واسم

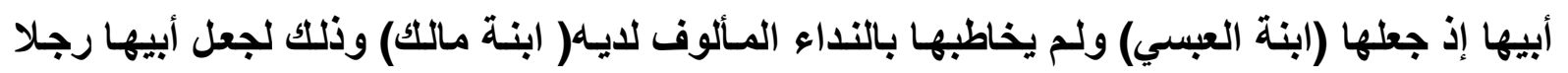
هامشيا من بني عبس لايقف هو أو أهي أمام حسب الثـاعر العبسي الذي صنعه في الدهالي الحرب والقتال .

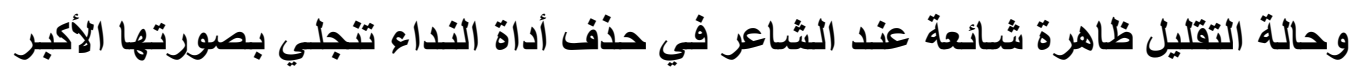

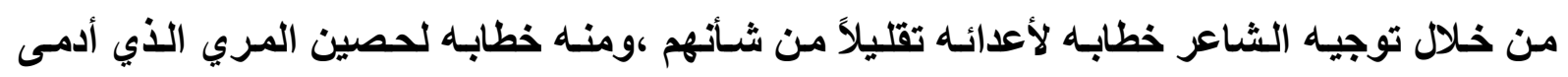

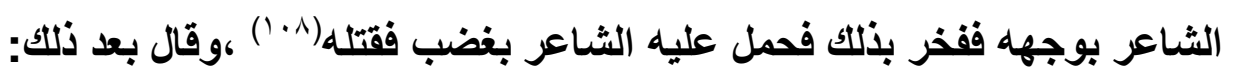

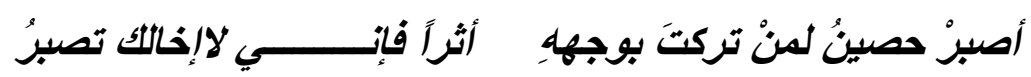

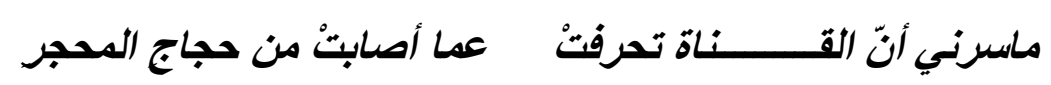

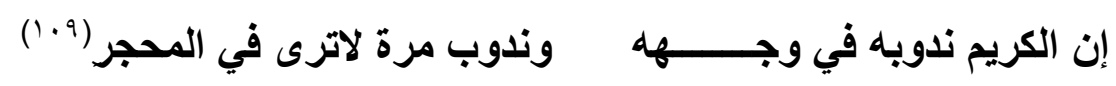
إذ يأتي الفعل (اصبر) قويا يقف بمواجهة المهجو ( حصين) ويأتي حذف أداة النداء

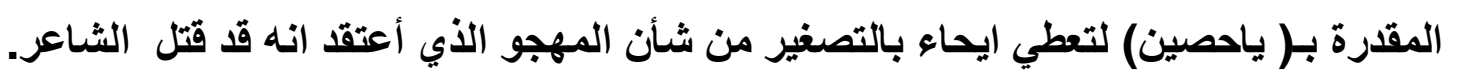

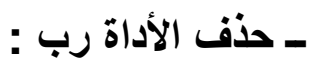

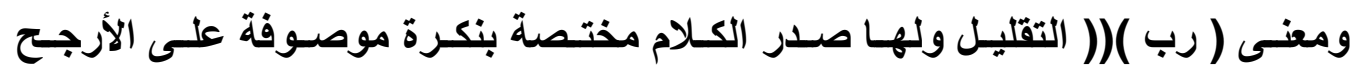

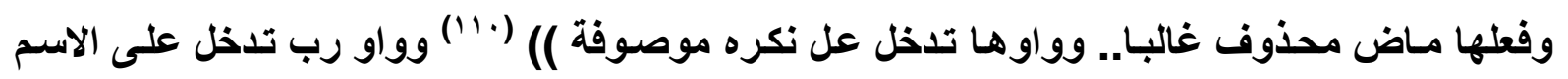

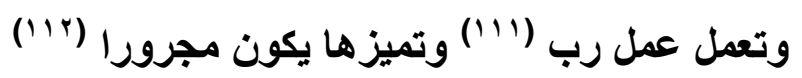

(107) ديوان عنترة : Tro.

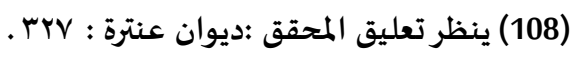

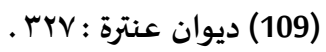

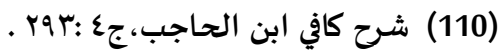

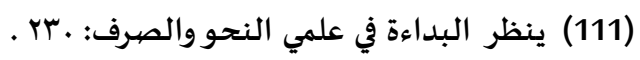

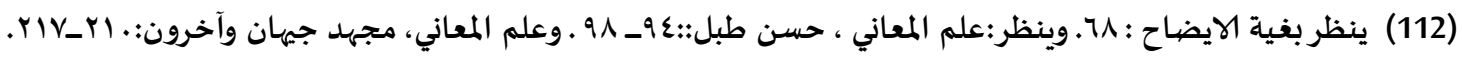


وتحذف الاداة رب عند الشاعر وأتت في كثير منها الغايـة من الحذف فيها الكشف عن حالة المسارعة وكثر ذلك في صوره التي تجسد مواقف الحرب والنزال التي وقف بها الشاعر وقد يصبح حذفها ضرورة فنية كما في قوله

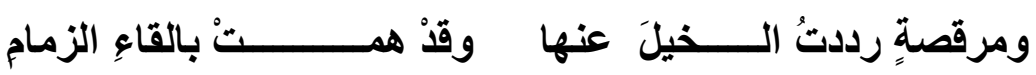

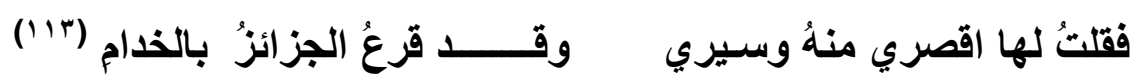

النص يصور فرار امرأة من الأعداء وإسراع الفـارس الشاعر في استنقاذها منهم إذ

تثقدم واو ( رب) التي تـم حـفها مبالغـة في إعطـاء طـابع السرعة المتواشـج مـع موقف الفـرار والاستتقاذ المتسارعان ويبدو أن صساحب النص قد حشد الألفـاظ والأفعـال الرافدة للموقف المتقدم (فمرقصة) صفة المـرأة ( الموصـوف المحذوف) قد أوحى بحذفهـ ولفظـه بالسرعة والعجلـة وتـأتي الأفعال( رددت، همت ، قرع) لتدخل هي الأخرى في الموقف المتسارع، كمـا أن حركة( قرع الجزائز

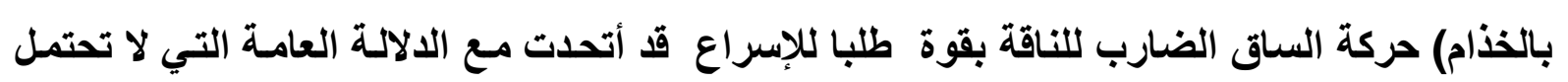
التأخير، ولهذا أصبح مما تقدم حذف الأداة ( رب) أصبح ضرورة فنبـة يتم بـه حفظ الإطار الصوري المراد بثنه إلى المتلقي.

وكمـا تقدم فحذف الأداة (رب ) جـاء في جاتبـه الأغلب في وصـف المعـارك التي خاضها الشاعر وقد تلتحم الألفاظ كلها في خدمة الموقف المتسارع وقد يلقي الشاعر بـأكثر من حذف وصـولا لحالـة الاسـتمرار الباثـة للاندفاع ، وقـد تجسد ذلـك في قولـه في التقـاء خيل الشاعر بخيل الاعداء:

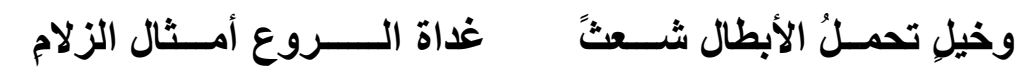

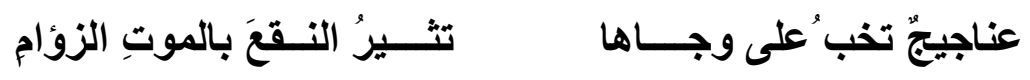

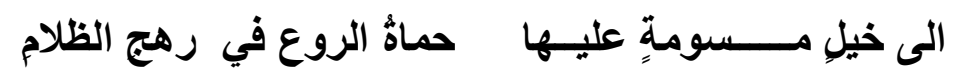

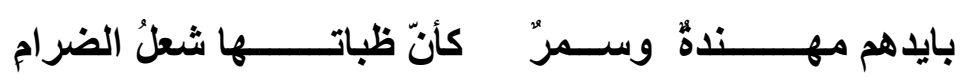

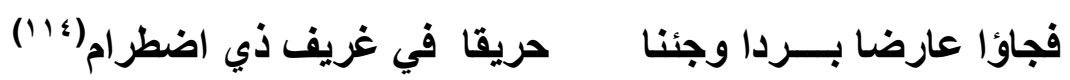
إذ تثقدم ( واو رب) لترتبط بلفظة ( الخيل) وسيلة السرعة والقتال الخاصـة بالشاعر و تختفي الأداة (رب) لتعمل على انسياب المشهـ الحربي المتسارع الذي تزيـ من أثره المتسارع الألفاظ ( تخب على وجاها)و( تثير النقع)، ( شعل الضرام)(ذي اضطرام)( جاؤ اـ جئنا) ويبدوأ حذف 
الأداة (رب) فـي لفظـة (خيـل) والمقدرة بــ( ورب خيـل) قــ أسـهمت وتـساوقت مـع المــ الانفعـالي

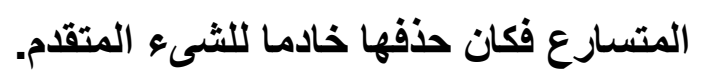

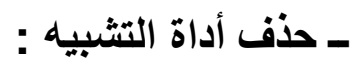

وقد يسعى الشاعر إلى جلب صور تشبهية متلاحقة تصور موقفا مـر إزاءه فيأخذه

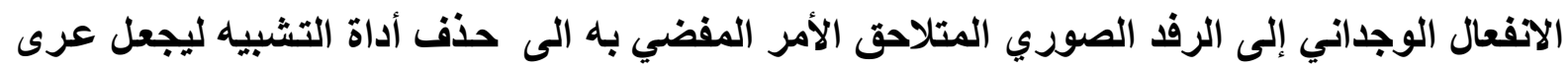
النص متلاحقة ومتلازمة في الوقت نفسه، ومنه قوله واصفا جمال المعشوقة:

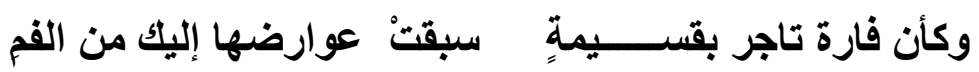

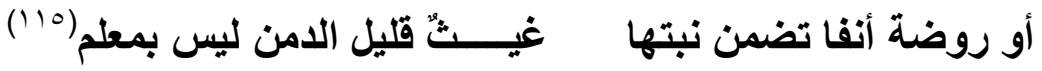

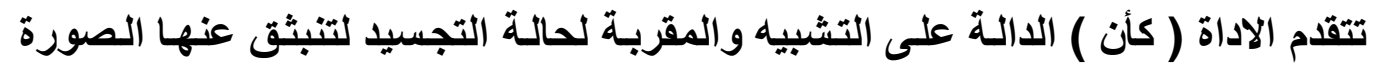
الثمية (فارة تاجر) التي تحول الحبيبة إلى ماهية شمية قادرة على النفاذ والتغلفل في نفس الشاعر

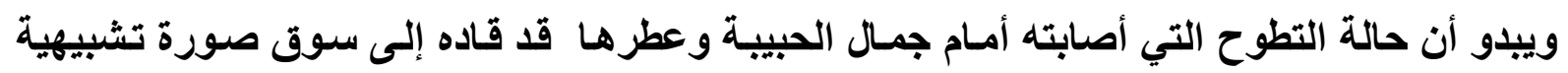

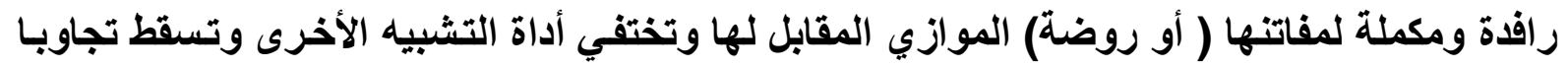
مع المد الانفعالي الذي استوثق صاحب النص ليقوده إلى صور أخرى متلاحقة ومتلازمة العرى (أنفا،

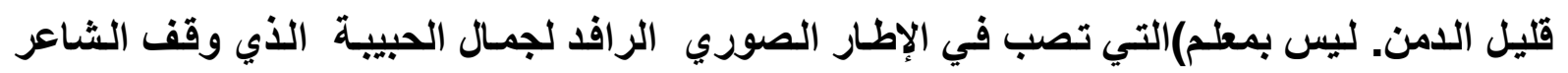
أمامه في حالة انسراب عاطفي منثال. - حذف الجار والمجرور:

ويجوز في كلام العرب حذف الجار والمجرور (1'1') ويأتي عنده حذف الجار والمجرور وتكون دلالاته متنوعة وقد تكون القصدية من وراء الحذف متنوعة ومثال ذلك قولهي:

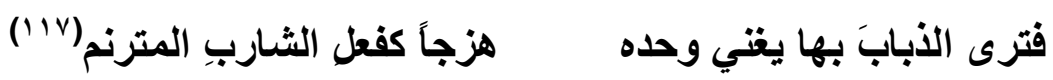
الثاعر إزاء وصف طل المعثوقة ويأتي الفعل( ترى ) رغبة بتجسيد الحالة وتقريبها

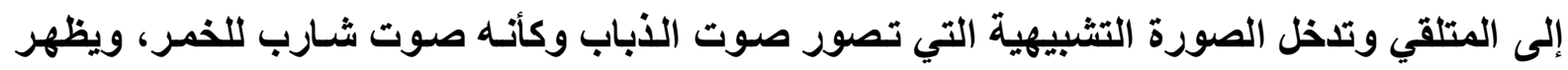
الثاعر وقد أركز لفظة (الشارب) هاملاً (للخمر ) التي تكمل دلالتها وقد يكون السبب القابع وراء

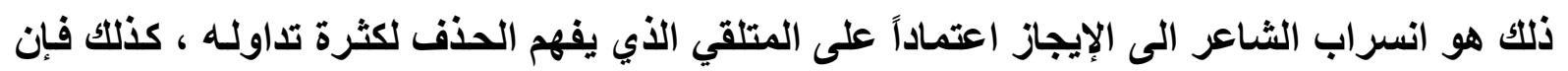

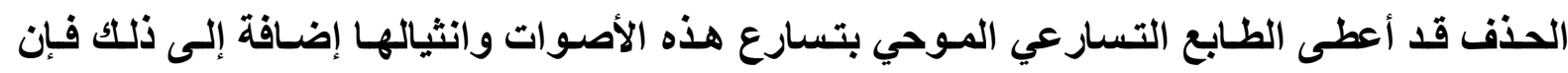

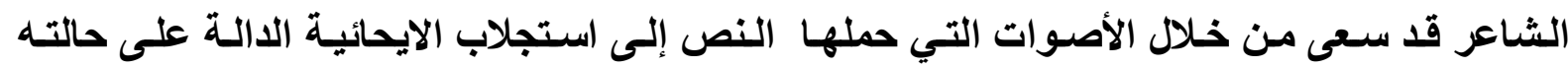

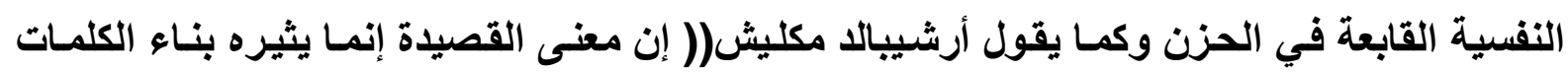


كأصوات أكثر مما يشيره بناء الكلمات كمعان وذلك لأنّ التكثيف للمعنى الذي تشعر به في أي قصيدة

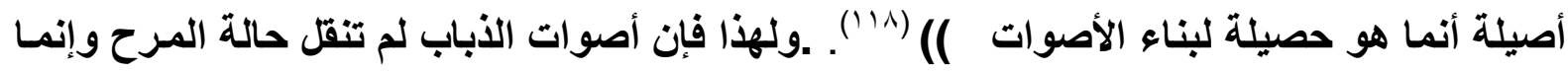
نقلت حالة الحزن الدال على العزلة والتوحد الذي نقل حالة الثـاعر الواقف بدار الأحبة الراحلين . وتبدو الدلالة المطلقة بيّنة في الجسار والمجرور فهو يسعى إلى جعل الحذف مفتوح

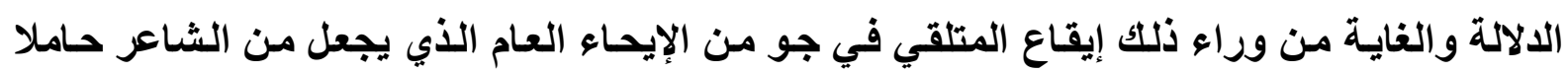
للصفات المفتوحة المتعددة التي ترفع من مكانة الثاعر ومنه قوله:

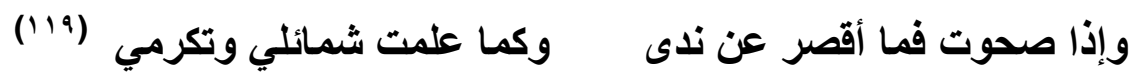

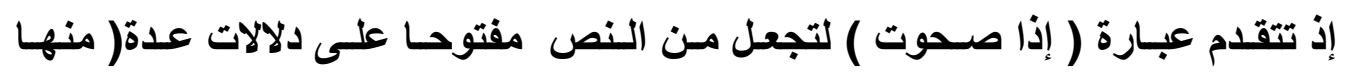

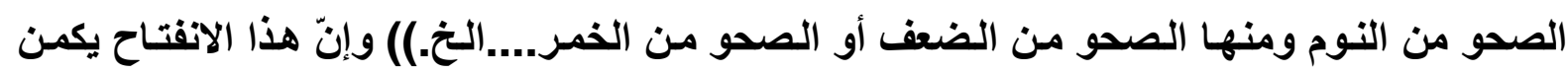

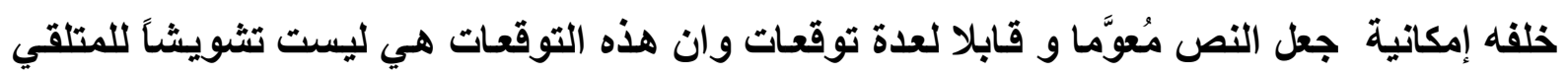
بقار ما تكون استدراج لذهنه من أجل إيقاعه في توقعات عدة تهلف إلى غمر دلالة (الصحو) العائدة

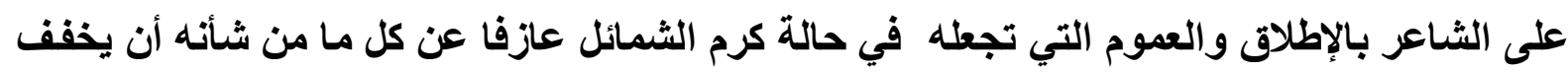
من حدة أثرها أو يقلل من شأنه.

ويحذف الجار والمجرور عند الشاعر وذلك لأنّ وجوده قد يعمل على قطع انسجامية

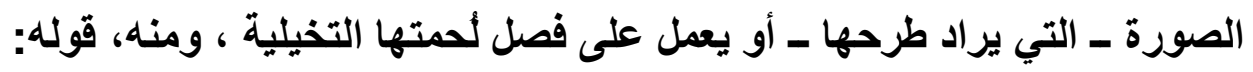

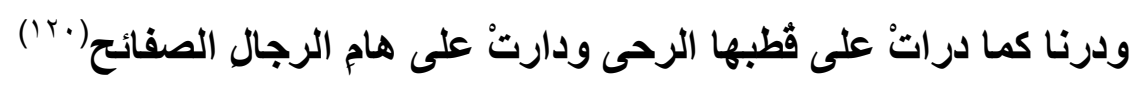

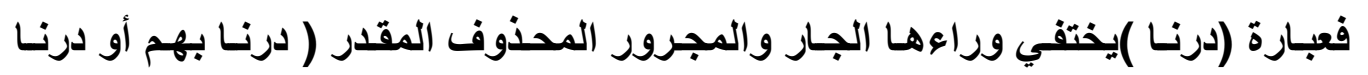

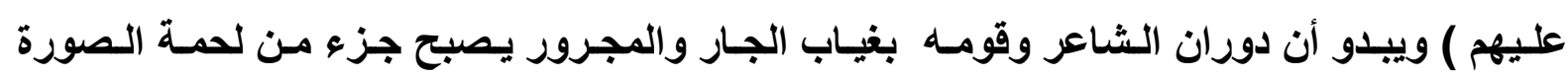

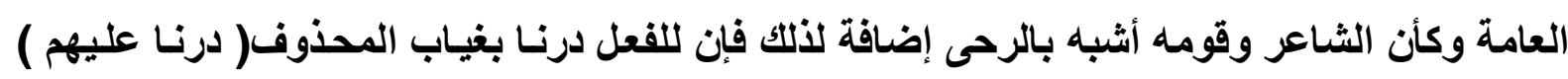

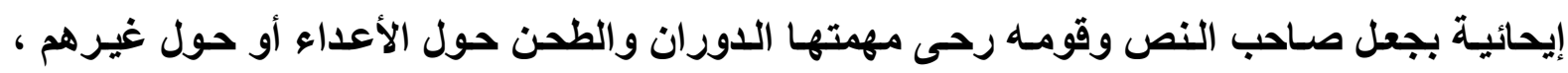
مبالغة بشجاعتهم.

و قد يحذف الاسم المجرور فقط لالالة التوسع التي تفضي إلى دلالة المبالغة ويظهر

ذلك في مشاهد الحرب التي يوسع الشاعر من دلالتها رغبة في خلق جو يبين شجاعته ومنه ، قوله:

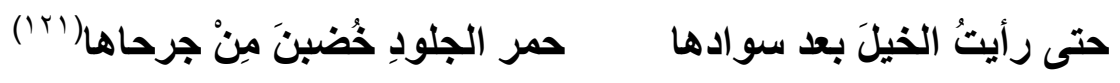


فالمحذوف هو الاسـم المجرور في ( خضبن مسن جرحاهـا) والتقدير (خضبن مسن دم

جرحاها) وذلك لتبيان شدة الحرب التي خاضها الشاعر الفـارس فالصورة المطروحة ( الخيل السود أصبحت حمرا من الجرحى) والصورة الكامنة في المدلول المحذوف ( الخيل السود أصبحت حمرا من دم الجرحى) ومعروف أن الغاء لفظة(دم) والاتكال على لفظة ( جرحى) في صبغ الخيول قد أعطى إيحائية بكون الجرحى قد تغطت أجسادهم كلها بالدم وكأنمـا جرحوا في كل مكان ،ووراء ذلك تظهر شجاعة الشاعر الذي خاض غمار هذه الحرب . وقد يقوم الحذف عند الشاعر لوجود مايدل عليه ولهذا يصبح الذكر في ذلك هو من من فره باب الإطالة التي لا يتوصل معها الى شيع ذي قيمة بل قد تعمل على ايقاع النص في عملية تفتقر

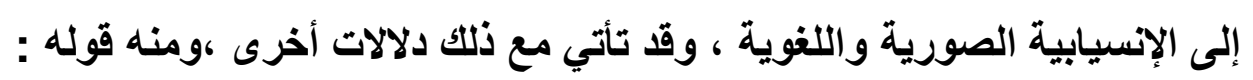

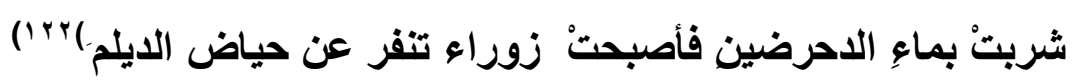
إذّ يتقدم الفعل ( شُرب ) ليرتبط بلفظة الدحرضين الدالة على مكان معين مرت بـه ناقة الثاعر ثثم تأتي عبارة ( تنفر عن حياض الديلم ) التي يختفي خلفها الاسم المجرور ( شرب وتقدير الجملة يكون( تنفر عن شرب مساء الديلم) ولذا فلا حاجة إلى ذكر( شرب )لأنه من بـاب الإطالة التي لايتوصل بها إلى شيء وحذف الاسم المتقدم ( شرب) في ( تثفر.... عن حياض الديلم) أعطت دلالة أخرى وكأن ناقة الشاعر في شموخها لاتنفر من الثرب فقط وإنما من الحياض كله ليبين فرادتها وانميازها عن سواها. وقد يكون حذف الجار والمجرور هو حالة ليست حالة مسارعة بقدر مسيكون حالات إثبات الثيء المقدم وإعطاء الإيحاء بحالة الثبات التي تمثلت في نفس قائله، يقول الثـاعر: بكرتْ تخوفني المنون كأنتّي أصبحتُ من عرض الحتوف بمعزل

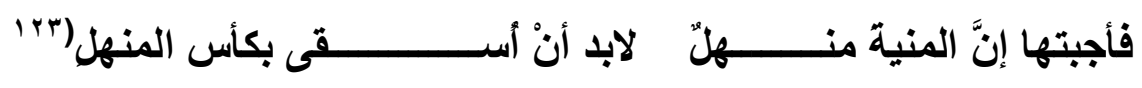

إن اللائمـة التي وقفت إزاء الشـاعر تقدم أمامـه طرحا من الطروح التي يقف أمامها وهي حالة التخويف من الموت بيد أن الشاعر الذي يحس بالثبات لا يخشى من ذلك ولذلك يتقدم الفعل( أجبتها قويا هادرا)وذلك ليقف إزاء الثيء المقدم فالثاعر لايعترف بماتقوله ولهذا فأن الطرح المقدم منها هو طرح غير ذي أهمية ولذلك يحذف الكلام الجـاوالمجرور ( عن سؤالها ) ويصبح في عداد المحذوفات لأن جوابه حاضر في نفس الشاعر المتيقين من مجيء الموت الذي لايمنعه الفرار 
وقد يحذف الجـار والمجرور لإعطاء الدلالة العامـة المطلقة التي يخرج منهـا الشـاعر إلى الدلالة التي تعطي إطارا مدحيا أكبر أو أطار ذاذيا ومن ذلك قوله:

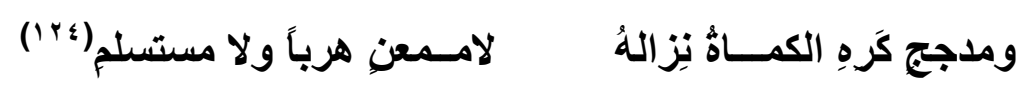

تتقدم واو رب التي تخفي وراءهـا( رب ) المحذوفة طلبـا للمسارعة التي تتجـاوب

والحالة التي يحـاول الشاعر أن يضفيها على الفـارس الموصوف بها وتأتسي عبارة ( كره الكمـاة) لتعطي الحد الأعلى من الشجاعة وتأتي( ولامستلم) لتخفي وراءها ( الجار والمجرور) المحذوفين وتقدير هما( ولامستسلما للأعداء) ويظهر أنّ الحذف في الجار والمجرور قد أعطى عمومية انعدام استسلام الشـاعر ليس فقط من الأعداء بل من أي شك ضمن أطسار الحياة وفي ذلك تفخيم وتضخيم لصورة المقاتل. فالثـاعر يرفض الاستغراب الأي قامت بتوجيهه الحبيبة من شدة نحوله فجـاء الجواب متسار عا بحذف الجملة من(امـا تريني قد نحلت) والحذف بعدها (امـا تريني فلا تتعجبي من مظهر التحول الذي لف جسمي وجعله غير جذاب.....) لأنسه يريــ الـاخول مباشرة للجواب بهدف رفض الاستغزاب المتقدم بحالة من الفخر. وقد يكون وراء حذف الجار والمجرور لوجود مايدل عليه ويكون ذكره من باب التكرار ،ومنه قوله:

طربت وهاجتّك الظباء السوانح غداة غدا منها سنيح وبارح (ror)

$$
\text { ـ أهم النتائج التي توصل إليها البحث ـ - }
$$

اــ استعمل الشاعر أسلوب الحذف من أجل إعطاء العمومية لكثير من الشواهد التي تعطي

$$
\text { إطارا أكبر للصورة التي يقدمها في طروحاته. }
$$

r ـ الحذف قد يهدف إلى إيحاء التقليل أو إيحاء التكثير وذلك بحسب السياق الذي يعمل على ضبط أطره وارتكاز اتها.

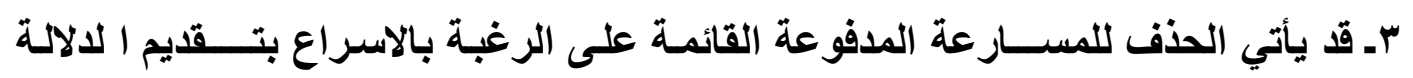
العامة الأهم ايمانـا بقدرة المتلقي بإكمال الرصد. عـ الحذف عند الشاعر كان يخفي وراءه هواجس نفسية متنوعة ضربت عميقا في نفسه فحبسها بيد أن السياق كثفها وفضح تصواراتها. 
هـ الشاعر كـان يهدف إلى كسر القالب النحوي المـألوف من أجل إخراج النص نحو دلالات متنوعة كذلك لتحفيز المتلقي للمتابعة والرصد .

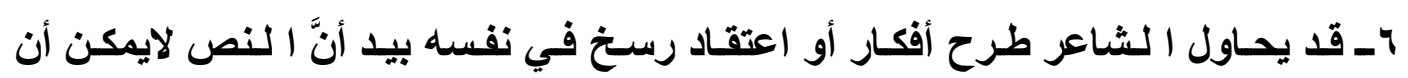

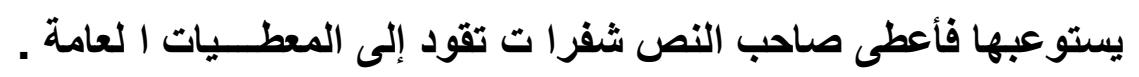

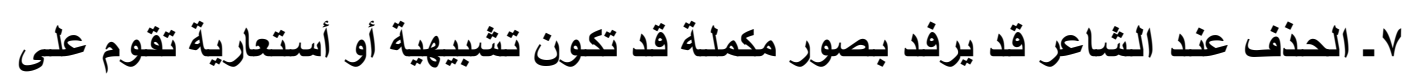
تكميلها والحفاظ على إطارها العام. ^ـ قد يأتي الحذف عند الثاعر خوفا من التكرار الذي لايقود لفائدة وقد يعلق معه دلالات أخرى يستدعيها السياق وطبيعة الموقف التعبيري.

$$
\text { - }
$$

ـ الاتجـاه النفسي في نقــ الـشعر العربـي ، عبـد القـادر فيدوح، مطبعـة اتحساد الكتـاب

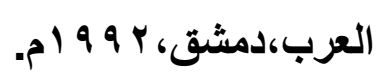

ـ الأسلوبية ، بير جيرو، ترجمة د. منذر عياشي، منشورات مركز الإنماء الحضاري طن ، . . ـ أقنعة النص' سعيد الغانمي ، طباعة ونشر دار الشؤون الثقافية ،طباعة آفاق عربيـة، ط ـ الأمل واليأس في الثعر الجـاهلي ، د. كريم حسن اللامي ، دار الثؤون الثقافية العامـة

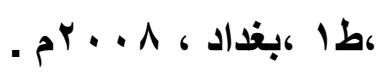
ــ بحوث منهجيـة في علوم البلاغة العربيـة ، ابن عبد الله أحمد شعيب، دار ابن حزم

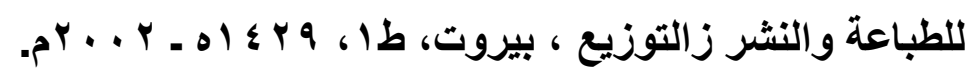

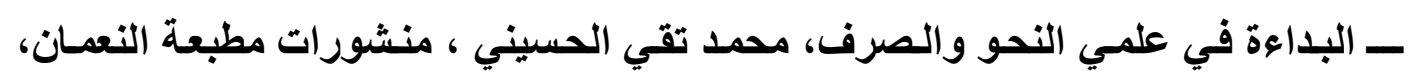
النجف، طץ PVV ــ البطولــة في الشعر العرب قبـل الإسـلام ،د.مؤيــ اليوزبكي ، منشورات دار الشؤون

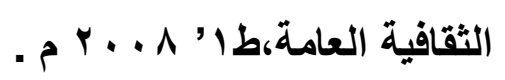
ـ بغية الايضاح لتلخيص المفتاح في علوم البلاغة،المعاني والبيان والبديع' عبد المتعال

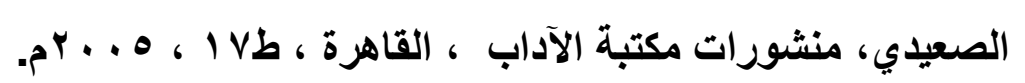

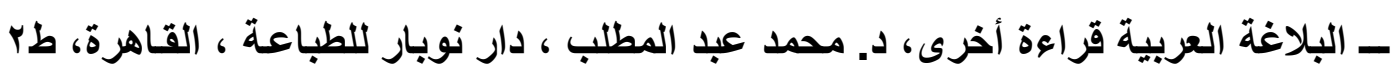
. . . . . 
ـ البلاغة فنونها وأفنانها ، علم المعاني،د.حسن فضل،، مكتبة الحسن لنشر والتوزيع ،

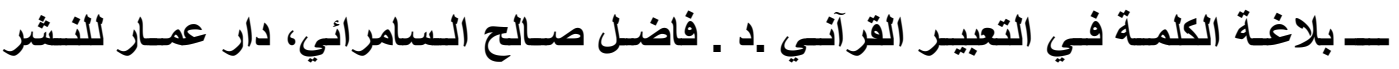

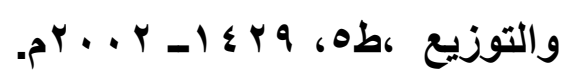

- بنـاء القصيدة الفنـي في النقد العربي القديم والمعاصر،مرشـد الزبيدي ، طبع في دار

الثؤون الثقافية العامة ، بغداد، ؛ 99 (م.ج جيل

- الثابت والمتحول، بحت في الإتباع والإبداع عند العرب،الأصول، دار العودة ، بيروت ،

ـ التحليل النقدي والجمـالي لـلأدب ،د. عنـاد غزوان ـ آفـاق عربيـة للصحافة والطباعـة

$$
\text { والنشر، بغداد ،د .ت. - مئ. }
$$

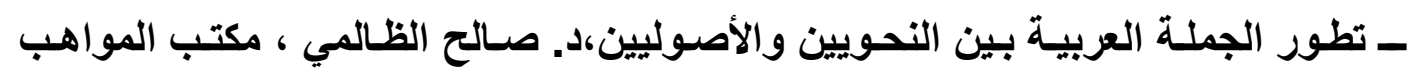

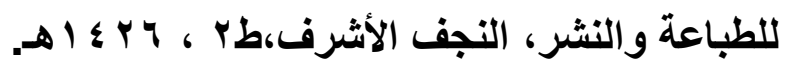

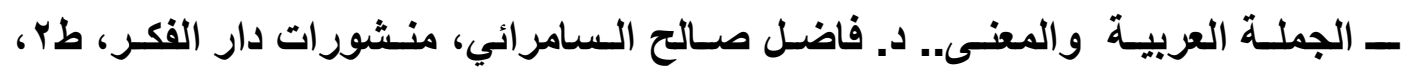

.

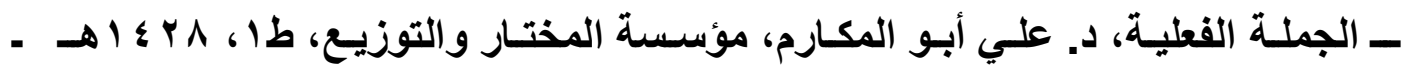

r..V

ـ- جـواهر البلاغـة ، أحمـد الهاثـمي” منشورات الأعلمسي للمطبوعـات ، بيـروت ، طا،

$$
\text { . r. N- } 1 \leqslant r q
$$

- دراسات المستشرقين حول صحة الشعر الجاهلي.د. عبد الرحمن بدوي،نشر دار العلم

للملايين،لبنان، طن ، 1919 م. 191 م.

ـ الدرر اللومع على همع الهوامع ، أحمدبن الأمين الثنقيطي، (ت مب إـ أهـ ، إعداد ،باسل

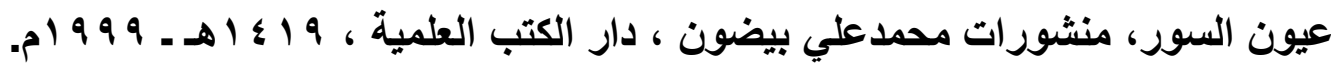

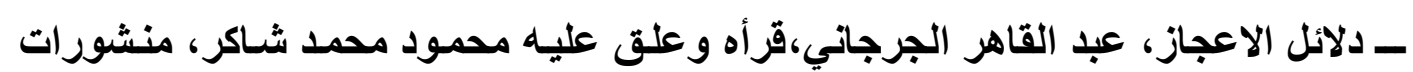

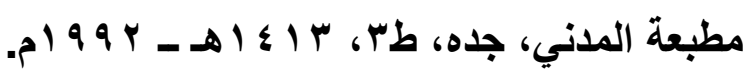
ـ ديوان عنترة ، تحقيق ودراسة( دراسة علمية محققة على ست نسخخ مخطوطة) رسالة ماجستير بالأصل من جامعة القاهرة، محمد سعيد مولوي، مكتبة جامعة بغداد الثانية،د.ت.

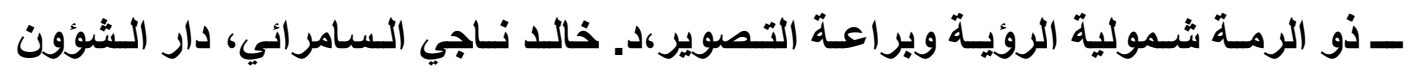

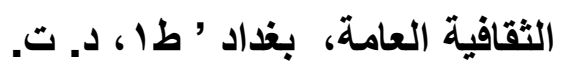


ـ شرح ابن عقيل على ألفية بن مالك، بهاء الدين عبد الله بن عقيل، تحقيق: محمد محي

$$
\text { الدين عبد الحميد، دار الغدير للطباعة والنشر، د. ت. }
$$

ـ شرح كافية ابن الحاجب ، تأليف : رضي الدين محمد بن الحسن الاستربادي، قدم لـه: د.

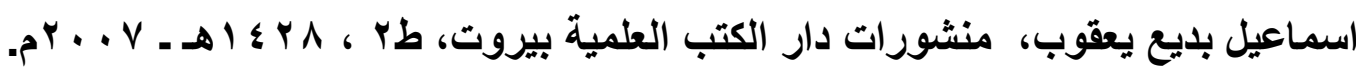
ــ الشعراء الصعاليك في العصر الجـاهلي ، ديوسـف خليف، منششورات دار المعسارف،

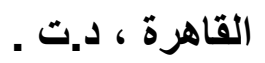

ــ الشعر الجـاهلي ،مـنهج في دراسـته وتقويمسه، ج ا، الناثـر ، الـدار القوميـة للطباعـة

$$
\text { والنشر، القاهرة، د.ت . - م. }
$$

ــ الشعر والتجربـة، أرشسيبالد مكليش،ترجمـة، سـلمى الخضراء الجيوسـي، داراليقضة

العربية للتأليف والنشر مع الاشتراك مع مؤسسة فرنكلين للطباعة والنشر ، بيروت، ب 9 ام. ـ علم المعاني، د. حسن طبل، ملتزم الطبع والنشر. مكتبة الإيمان، ط9 99 1 1، ام. ـ علم المعاني، د. قصي سالم علوان، طبع على نفقة جامعة البصرة، د...ت.

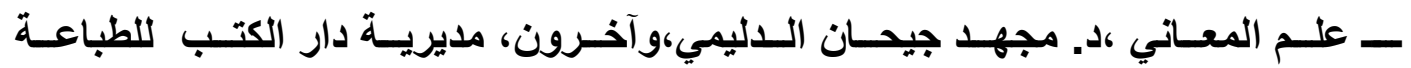

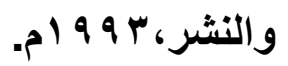

ـ علـوم البلاغـة : البـليع والبيـان والمعـاني، منششورات المؤسسة الحديـة للكتـاب، طا

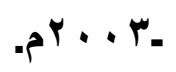

ــقاموس قواعد البلاغـة وأصـول النقد والتذوق، اعداد: مسعد الهواري، منشورات مكتبة الإيمان ، د.ت.

ـ كتاب الصناعتين الكتابة والثعر، أبو هلال العسكري، تحق:علي محمد البيجاوي ومحمد

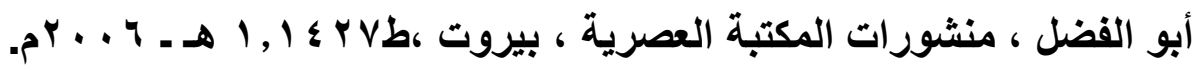
ـ مبادى النقد الأدبي، تـأليف أـ أ ريتشارد، ترجمة وتقديم د. مصطفى بدوي،منشورات المؤسسة المصرية العامة للتأليف والترجمة والنشر،مطبعة مصر، ب 9 أو م. ــ المـبـاح في المعساني والبيـان والبديع، الإمسام أبسي عبد الله بـدر الدين الشهير بـابن

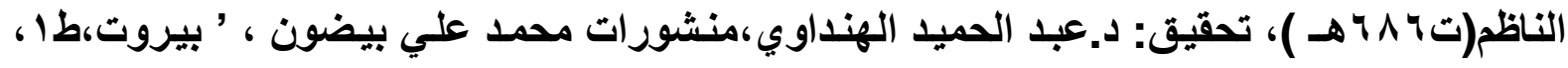

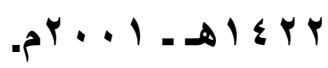
ـ المرأة في الشعر الجاهلي ، مطبعة المعارف ، بغداد ' . 9 أم ام . ـ المطول، شرح تلخيص مفتاح العلوم، مسعود بن عمر التفتازاني، تحقيق: عبد الحميـ الهنداوي، منشورات محمد علي بيضون طا ـ ـ ؟ \& أهـ 
ـ المنتخب في كلام العرب ، محمد جعفر الكرباسي، مطبعة الآداب، النجف، ب • ؛ اهـ ـ

$$
\text { م } 9 \wedge \mu
$$

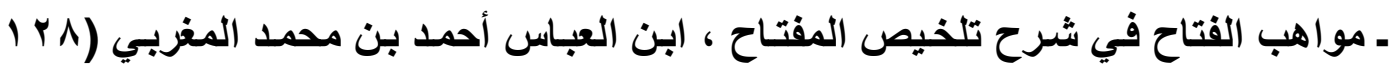

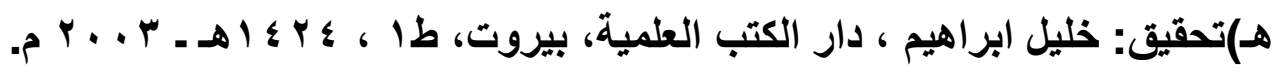

ـ نظرية البنائية في النقد الأدبي ،د صلاح فضل، منشورات دار الثوؤون الثقافية العامـة

$$
\text { بغداد، } 9 \vee V
$$

النظم الثفوي في الثعر الجاهلي ، جيمز مونرو. د.فضل بن عمار العمـاري، دار الأصـالة

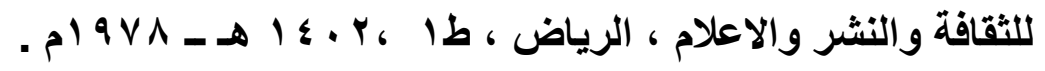

